\title{
Lawyering for a Cause and Experiences from Abroad
}

\author{
Jayanth K. Krishnan $\dagger$
}

\section{INTRODUCTION}

For decades, observers have discussed the various roles that lawyers can, and should, play in promoting social change. As far back as 1905, Louis Brandeis argued that although "[t]he leading [U.S.] lawyers" of the time were primarily concerned with protecting the interests of corporations, the bar had a responsibility to advocate for greater social and economic equality on behalf of the general public. ${ }^{2}$ Some years later, Benjamin Twiss challenged the prevailing perception of U.S. business lawyers as a homogenous group by documenting the anti-capitalist efforts of many of these lawyers during the late 1800 s and early 1900 s. $^{3}$ In 1950, Willard Hurst published his classic study in which he argued that the growth of American law since independence stemmed in part from the evolving presence of lawyers in both politics and society. ${ }^{4}$ And just two years later, Clement Vose, in his well-known book, Caucasians Only, recounted how lawyers from the NAACP successfully fought against private, restrictive property covenants that prohibited racial minorities from purchasing homes in all-white residential communities. ${ }^{5}$

As the civil rights movement gained momentum in the 1950s and 1960s, a group of talented lawyers-including Thurgood Marshall,

Copyright $(\mathcal{C} 2006$ Califomia Law Review, lnc. California Law Review, Inc. (CLR) is a Califomia nonprofit corporation. CLR and the authors are solely responsible for the content of their publications.

$\dagger$ Associate Professor, William Mitchell College of Law, St. Paul, MN. J.D., Ohio State University, Ph.D., University of Wisconsin-Madison. This study was completed while the author served as the 2005 British Academy Visiting Professor, University of Edinburgh (U.K.), Centre for South Asian Studies. For their insights, the author is grateful to Austin Sarat, Stuart Scheingold, Mare Galanter, Arun Thiruvengadam, and Tom Hilbink. For their comments on very early versions of this study, the author thanks Upendra Baxi, Kim Lane Scheppele, Gary Jacobsohn, and Phil Thomas.

1. See Louis D. Brandeis, The Opportunity in the Law, in Business: A Profession 313, 322 (1914). Brandeis gave the talk in which this chapter originated in 1905.

2. Id. at $339-40$.

3. Benjamin R. Twiss, Lawyers and the Constitution: How Laissez Faire Came to the SUPREME COURT (1942).

4. James Willard Hurst, The Growth of American law (1950).

5. Clement E. Vose, Caucasians Only: The Supreme Court, the NaACP, and the Restrictive Covenant CaSES (1959). 
Constance Baker Motley, Jack Greenberg, and others-rose in prominence by using litigation to champion the rights of minorities. Social-justice lawyering by these activists was touted as an effective strategy that could bring about positive legal and political change. Beginning in the 1970s, however, and continuing through the 1980 s, several scholars began to take a more critical look at these activist lawyers. In his highly cited 1970 study, for example, Stephen Wexler deseribed how poverty-rights lawyers often purposely overlooked the immediate needs of their clients in their efforts to achieve a greater good. ${ }^{6}$

Other studies soon followed, confirming the assertion that activist lawyers too often ignored input from their clients, interested parties, and potential political allies when determining how to advocate a cause. ${ }^{7}$ Such lawyers tended to concentrate on litigation, ignoring extralegal advocacy tactics with which their clients might be more familiar and comfortable. Lawyers were also criticized for their arrogance and for promoting strategies that aligned with their own skill sets. ${ }^{8}$ Lawyers, according to the critics, framed claims and mobilized constituents mainly through rights-based discourse and refused to devote necessary resources toward political and grassroots efforts. ${ }^{9}$

Yet for more than a decade a growing body of scholarship has been evaluating these critics' contentions. ${ }^{10}$ Two of the most prominent observers of activist, social justice, or what they call "cause lawyers" do are professors Austin Sarat and Stuart Scheingold. For Sarat and Scheingold, cause lawyering is defined as going "beyond a crude instrumentalism in which lawyers sell their services without regard to the ends to which those

6. Stephen Wexler, Practicing Law for Poor People, 79 YALE L.J. 1049, 1054 (1970). In this study, Wexler famously recited a disturbing case where a lawyer refused to mention to an indigent client that her child should seek medical treatment for a health condition. The lawyer worried that the client would be less enthusiastic about championing the cause if she had to devote more time to childcare. Id.

7. For a summary of this critique, see generally MiCHaEL W. MCCANN, RighTS AT WORK (1994) [hercinafter MCCANN, RighTs]; Michael McCann \& Helena Silverstein, Rethinking Law's "Allurement": A Relational Analysis of Social Movement Lawyers in the United States, in CAUSE Lawyering: Political Commitments and Professional Responsibilities 261 (Austin Sarat \& Stuart Scheingold eds., 1998) [hereinafter SARAT \& SchEINGOLD 1998]. On the alienating effect of this prioritization, see Timothy J. O’Neill, Bakke and the Politics of Equality (1985).

8. See generally Joel Handler, Social Movements and the Legal System: A Theory of Law Reform and Social Change (1978); Jack Katz, Poor People's Lawyers in Transition (1982); Susan M. Olson, Clients and Lawyers: Securing the Rights of Disabled Persons (1984).

9. See McCann \& Silverstein, in SARAT \& Scheingold 1998, supra note 7, at 262-64. See generally Gerald Rosenberg, The Hollow hope: Can Courts Bring About Social Change? (1991); Stuart A. Scheingold, The Politics of Rights: Lawyers, Public Policy, and Political Change (1974); Mark Tushnet, An Essay on Rights, 62 TEx. L. Rev. 1363 (1984) [hereinafter Tushnet, An Essayl.

10. A literature review of these rebuttal works is provided in Part III 
services are put."11 Instead, cause lawyers seek to "reconnect law and morality and make tangible the idea that lawyering is a "public profession,'... [where] lawyers [are] committed to using their professional work as a vehicle to build [a] good society [and to] help legitimate the legal profession as a whole."12 To accomplish their mission, cause lawyers can (and do) combine legal strategies with mass-based tactics, and they frequently develop important coalitions across the tactical spectrum to improve their clients' political power. ${ }^{13}$

In fact, for Sarat and Scheingold the essence of cause lawyering is that the lawyer seeks to create a legal and political consciousness that might lead a cause's constituents to participate in the political process. ${ }^{14}$ "[A]bstract programmatic eommitments," these lawyers. Instead, they act in versatile ways depending on their professional and political backgrounds, their role vis-à-vis the cause or the eommunity they champion, the resources available to them, and the overarching political and societal attitudes of the day. ${ }^{16}$

Over the years, Sarat and Scheingold have conducted copious research and collected rich empirical data to support their analysis of cause lawyering in the United States. What, then, is missing from the existing inquiry into what cause lawyers do and their normative value in promoting social change? In this study I argue that although the critics of cause lawyers on the one hand, and scholars like Sarat and Scheingold on the other, have made enormous contributions to the debate, only recently has the discourse shifted to an important element of cause-lawyering that, until now, has received limited attention. Building on this exciting new work, I suggest that scholars should consider more closely how people working on a cause at the grassroots level interact with, attempt to influence, and make demands

11. Austin Sarat \& Stuart Scheingold, Cause Lawyering and the Reproduction of Professional Authority: An Introduction, in SARAT \& SCHEINGOLd 1998, supra note 7, at 3.

12. Id. (internal citations omitted).

13. See, e.g., Austin Sarat \& Stuart Scheingold, Cause Lawyering and the State in a Global ERa (200I) [hereinafter Sarat \& Scheingold 2001]; Sarat \& Scheingold 1998, supra note 7.

14. For a general discussion of this idea of legal and political consciousness, see McCann \& Silverstein, in SARAT \& SCheingold 1998, supra note 7; see also Robert L. Kidder \& Setsuo Miyazawa, Long-Term Strategies in Japanese Environmental Litigation, 18 LAW \& SOC. INQUIRY 605 (1993).

I5. McCann \& Silverstein, in SARAT \& SCheıNGOLD I998, supra note 7, at 262. For commentary on the behavioral nuances that movement leaders can and do display, see Kevin R. Johnson, Civil Rights \& Immigration: Challenges for the Latino Community in the Twenty-First Century, 8 LA RAZA L.J. 42, 43-44 (1995) [hereinafter Johnson, Civil Rights].

16. These variables are drawn from McCann \& Silverstein, in SARAT \& Scheingold I998, supra note 7. 
of their lawyers, and how in turn these lawyers respond to such lay advocacy. $^{17}$

In Part I of this Essay I present a brief history of the rise of cause lawyering in the United States and the critiques of this phenomenon. In Part II I provide a set of rebuttals to these critiques, including a detailed discussion of the scholarly contributions of Sarat and Scheingold. I elaborate in this Part how Sarat and Scheingold's research, their findings, and even thcir purposive selection of the term "cause lawyer" have significantly advanced our understanding of this subject. ${ }^{18}$

In Part III I expand on my assertion that individuals involved in causes at the grassroots level - and in particular grassroots leaders and activists-can impact their lawyers' tactics in substantive ways. ${ }^{19}$ To show the extent of this grassroots influence, I look beyond easily identifiable activist practices such as boycotts and protests. Instead I focus on arguably the most formal, technical tactic, one that Sarat and Scheingold acknowledge remains key to cause lawyering: constitutional litigation. ${ }^{20}$

By drawing on the language of constitutional rights, cause lawyers often engage in translating the immediate needs of their constituencies into

17. Several works are currently beginning to investigate the role of social-movement constituents on cause-lawyering behavior. In fact, to their credit, Sarat and Scheingold are editing a forthcoming book on this exact topic. See Austin Sarat \& Stuart Scheingold, Cause Lawyers and Social Movements (forthcoming 2006) [hereinafter SaRat \& Scheingold 2006l. For a select set of scholars writing in this area, see Kevin den Dulk, In Legal Culture, But Not of It: The Role of Cause Lawyers in Evangelical Legal Mobilization, in SARAT \& SCHEIngold 2006, supra; Thomas Hilbink, The Profession, the Grassroots, and the Elite: Lawyering for Civil Rights in the Direct Action Era, in Sarat \& Scheingold 2006, supra; Lynn Jones, The Haves Come Out Ahead: How Cause Lawyers Frame the Legal System for Movements, in SARAT \& SCHEINGOLD 2006, supra; Anna-Maria Marshall, Social Movement Strategies and the Participatory Potential of Litigation, in SARAT \& SCHEINGOLD 2006, supra. Prabha Kotiswaran recently has argued that, in fact, lay constituents can themselves take on the de facto role of the lawyer. Prahba Kotiswaran, Cause Lawyering for the Sexual Subaltern: The Case of the Indian Sex Workers' Movement (2005) (unpublished paper presented at the Law and Society Conference 2005, on file with author). As she puts it, these "lay-lawyers" often are more in tune with the movement, and the frequent disconnect between the professional lawyer and the grassroots constituents results from the former simply not being aware of the latter's needs. Id. Kotiswaran emphasizes thc lay-lawyer dimension (she, in fact, calls for an expansion of the term "cause lawyer"). My study concentrates on how grassroots activists can help professional cause lawyers formulate specific tactical strategies, including, arguably, the most formal of strategies, constitutional litigation. Id.

18. Stuart A. Scheingold \& Austin Sarat, Something to Believe in: Politics, Professionalism, and Cause Lawyering (2004) [hereinafter Scheingold \& Sarat 2004]. This book is the only one of their combined efforts in which Professor Scheingold's name is listed before Professor Sarat's. In the text 1 refer to both scholars with Professor Sarat's name listed first.

19. 1 distinguish between leaders, organizers, and regularly engaged activists at the grassroots level on the one hand, and those who play more of an occasional, ephemeral, or marginal role on the other. 1 will focus on the work of the former in influencing cause lawyers, although I certainly recognize that grassroots leaders, organizers, and activists can take their cues from lesser involved constituents.

20. Their most recent book highlights this point. See SCHEINGOLd \& SARAT 2004, supra note 18, at 103-04; 121-31. Here I presuppose that the constitution the cause lawyer is drawing on is liberal and democratic in nature. 
actual legal claims. Because the cause lawyer is procedurally familiar with filing complaints and skilled in crafting substantive legal arguments, she is in a unique position to draw upon and effectively use constitutional rhetoric to represent her constituents' cause in court-as well as in the political sphere more generally.

Of course, that lawyers frame their arguments to conform to constitutional language comes as no surprise to those who have studied U.S. lawyers. ${ }^{21}$ But not enough critical scholarship has examined why cause lawyers invoke such rhetoric. The conventional assumption in legal scholarship on U.S. cause lawyers is that the decision to use this strategy comes from the lawyers themselves. After all, the lawyers are the experts who are skilled in this rhetorical practice and, thus, are best able to determine how and when to employ this strategy.

The second half of Part 11 I focuses on three different grassroots movements - the women's movement, the civil liberties movement, and the environmental movement - in a different constitutionally-based and democratic society: India. These movements illustrate Indian grassroots leaders' involvement in assisting their lawyers, especially in recasting the pressing concerns of everyday individuals into constitutionally recognizable claims." As I will explain, the United States and India share a number of important legal and constitutional similarities that makes such a comparative investigation useful. Many might think that because issues of caste and other socioeconomic and political cleavages remain starkly present in India, such "bottom-up" pressure would be rather unlikely. But, as my findings and conclusion suggest, such pressure indeed is occurring in India, offering those who study cause lawyering and constitutional litigation in the United States an opportunity to reexamine the interaction between grassroots activists and the lawyers who work on their behalf.

\section{Lawyers as a Font for Social Change: The Elitism Critique}

Many scholars have long chastised social-activist lawyers for being out of touch with the needs and concerns of those they represent. ${ }^{22}$ For example, Professor Derrick Bell, a former lawyer for the NAACP Legal Defense Fund, argued nearly thirty years ago that he and many of his colleagues miscalculated the significance of using litigation to champion the

21. For a classic case supporting this point, see ANTHONY Lewis, GIDEON's TRUMPET (1964) (describing how lawyers connected the formal issue of the right to counsel with the immediate problems facing Gideon and people in his situation).

22. Some of the literature cited, referenced, and reviewed here comes from the comprehensive bibliography provided by McCann \& Silverstein, in SARAT \& SCHEINGOLD 1998, supra note 7, at 28892. 
cause of racial balance in U.S. school districts. ${ }^{23}$ Civil rights lawyers so vociferously pressed the rhetoric of achieving numerical equality in schools that, along with judges and policymakers, they often prioritized integration for integration's sake over ensuring that minority children received strong educations..$^{24}$ On paper, the Brown v. Board of Education ${ }^{25}$ decision and later court victories, validated the integrationist agenda, but, aecording to Bell, ignored the real-life plight of millions of African Americans who continued to lack access to quality educational opportunities. $^{26}$

Other studies soon followed which also questioned the wisdom of having lawyers serve as leaders of social causes. Joel Handler, in his 1978 project on lawyers and social movements, discovered that lawyers often sought to manipulate and cajole poorer group members into pursuing litigation rather than alternative modes of social change. ${ }^{27}$ In his 1982 book on the Legal Services Corporation, Jack Katz found that an efficient division of labor occurred between legal aid lawyers who worked in neighborhoods (and provided more grassroots assistance) and those who worked in downtown areas (and provided litigation assistance). However, when a lack of resources forced decisions to be made between pursuing causes in court or through politics, the lawyers typically opted to select the legal path, even if that came at the expense of client demands. In a much harsher condemnation, that same year Marshall Breger argued that Legal Services lawyers tended to take on only those clients whose cases matched the lawyers' own ideological biases, paying little attention to or altogether ignoring other potential clients. ${ }^{28}$ Scholars further underscored this type of sentiment regarding social-activist lawyers over the next several years.

Consider, for example, the number of works that emerged in 1984 alone. In that year, Peter Gabel and Duncan Kennedy published their wellknown parody of lawyers as compulsive actors who sought to "translate"29 the concerns of everyday people into a discourse that only lawyers could understand. Susan Olson's 1984 work on the rights of the disabled showed that the "dissociation" 30 that Gabel and Kennedy believed existed between lawyers and their clients could be minimized, but only when grassroots activists, and not just lawyers, participated in shaping the political and

23. Derrick A. Bell, Jr., Serving Two Masters: Integration Ideals and Client Interests in School Desegregation Litigation, 85 YALE L.J. 470 (1976); see also MARK V. TushNET, THE NAACP's Legal Strategy Against Segregated Education, 1925-50 (1987).

24. Bell, supra note 23 , at 516.

25. Brown v. Bd. of Educ., 347 U.S. 483 (1954).

26. Bell, supra note 23 , at $475-516$.

27. HANDLER, supra note 8 .

28. Marshall Breger, Legal Aid for the Poor: A Conceptual Analysis, 60 N.C. L. REv. 282. 324 (1982).

29. Peter Gabel \& Duncan Kennedy, Roll Over Beethoven, 36 Stan. L. Rev. 1, 26 (1984).

30. Id. 
legal strategies of the movement. ${ }^{31}$ In fact, as Stephen Wasby uncovered in his 1984 study, lawyers were not the most apt champions of a cause, even in terms of litigation. ${ }^{32}$ Similarly, Mark Tushnet pointed out that same year that advocating issues through contemporary rights-talk was inherently indeterminate at best, and at worst "impede[d] [real] advances [in] progressive social forces." 33

Throughout the $1980 \mathrm{~s}$, other studies evaluating the role of lawyers emerged. ${ }^{34}$ Then in 1991, Gerald Rosenberg published his powerful book, The Hollow Hope..$^{35}$ Rosenberg focused on whether traditionally underrepresented movements are best served by turning to the judiciary to bring about social change. ${ }^{36}$ Given the institutional constraints facing the judiciary, which neither controls the congressional purse nor directs the military, and the constitutional limitations on the cases it can take, courts, Rosenberg claimed, cannot sua sponte make substantive social change. ${ }^{37}$ Yet because activist lawyers either are unaware of this point or simply disregard it, the movements they lead often spend their limited resources on strategies that yield minimal results, rather than on strategies that enhance political mobilization. ${ }^{38}$ One year later, Gerald López made a related criticism of "progressive" lawyering in his book on the interaction between lawyers and minority communities. ${ }^{39}$ More bluntly, Mary Ann Glendon has noted that the "premature and excessive resort to the courts ... has been a disaster for the political health of the country."40

The underlying theme of these works is consistent: a disparity exists between the cause lawyers' visions of the transformative power of the law and the realities of the communities they represent. But there are those, most notably Professors Sarat and Scheingold, who offer another perspective to this discussion, the development of which I explore in the next Part.

II

Sarat and Scheingold: The Many Sides of the "Cause Lawyer"

\section{A. Prefacing the Sarat-Scheingold Project}

Implicit in the aforementioned critique is that cause lawyers simply fail to follow a tenet of the legal profession: a lawyer needs to maintain

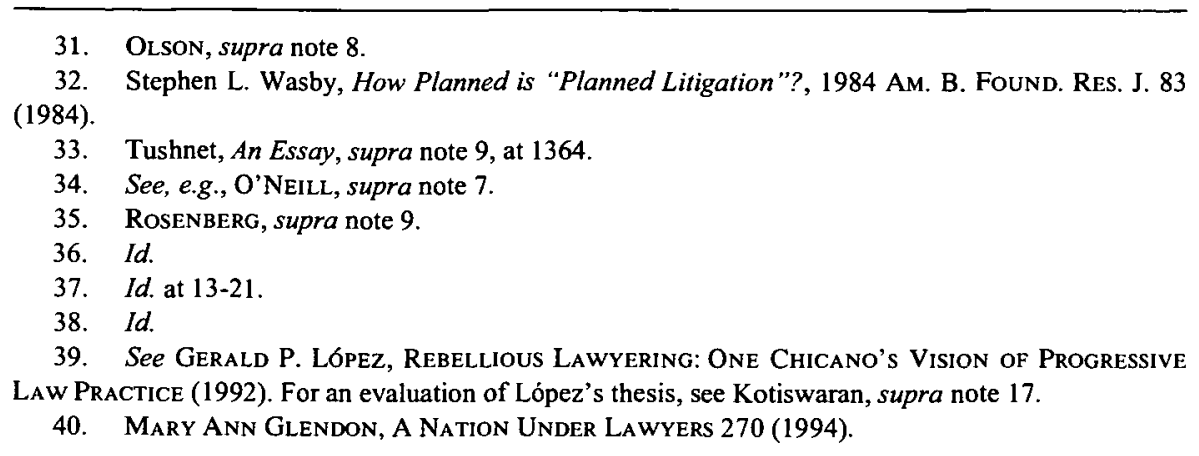


what Max Weber might call a rational distance from the client, whereby the lawyer is careful not to step outside the sphere of neutrality that embodies her role as a professional advocate. William Simon discussed this "legal professionalism norm" ${ }^{91}$ nearly thirty years ago, noting that although the lawyer is charged with zealously defending her client's interests, principles of professional conduct recommend retaining a detached, impartial stance toward the larger implications of this advocacy. ${ }^{42}$ The argument was that if the legal professionalism norm was violated, and lawyers started to be identified with, particularly, their less-popular clients, the negative image associated with the clients might be transferred to the representing lawyers, not to mention to the rest of the bar. ${ }^{43}$

Thereafter, a series of empirical studies sought to challenge Simon's position and the above critics' views. In 1994, for example, Michael McCann published his well-known book on lawyers and the pay-equity movement in the United States. ${ }^{44}$ McCann found that many of the lawyers he studied were not one-dimensional, litigation-focused actors. Certainly, litigation was an option. But in general, most of the lawyers he observed viewed litigation as just one in a range of available tactics. For practical purposes, this had to be the case. Litigation took time, and given the pressures lawyers faced from constituents and funders, movements simply could not ignore other options that might well bring faster results. ${ }^{45}$ Moreover, even if a movement did prevail in court-which obviously was no guarantee-there was still the concern that a favorable judgment would not make an immediate difference in the lives of those on the ground. ${ }^{46}$

Thus, McCann found that lawyers who used the courts viewed litigation as a pragmatic tactic that offered both direct and indirect benefits-for example, attracting political attention or raising public awareness of a cause. $^{47}$ Many of the lawyers did coordinate litigation with other

41. This is the term 1 assign to this norm, although it draws on Weber's and Simon's discussion.

42. William Simon, The Ideology of Advocacy: Procedural Justice and Professional Ethics, 1978 WIS. L. REv. 29, 36 (Lawyers are taught two "principle[s] of conduct. [One] principle prescribes the lawyer remain detached from his client's ends ... The second principle of conduct is partisanship. This principle prescribes that the lawyer work aggressively to advance his client's ends.").

43. Id. at 41 ("[A] lawyer's neutrality is essential to the proper performance of his basic task ... Since the legal system is independent of personal ends and social norms, the lawyer's ends and his notions of social norms have no relevance ... . Because ends are individual, subjective, and arbitrary, if the lawyer attempted to take his ends into account in advising his client, he would reduce the ... effectiveness of his services.").

44. MCCANN, Rights, supra note 7.

45. Id.; see also Stephen L. Wasby, Race Relations Litigation in an Age of Complexity (1995); Kevin R. den Dulk, Prophets in Caesar's Courts (2001) (unpublished Ph.D. dissertation, University of Wisconsin-Madison).

46. See MCCANN, Rights, supra note 7.

47. Id:; McCann \& Silverstein, in SARAT \& SCHEINGOLD 1998, supra note 7, at 267; see also Carrie Menkel-Meadow, The Causes of Cause Lawyering: Toward an Understanding of the Motivation and Commitment of Soeial Justice Lawyers, in SARAT \& SCHEINGold 1998, supra, at 31; Stuart Scheingold \& Anne Bloom, Transgressive Cause Lawyering: Practice Sites and the Politicization of 
strategies. ${ }^{48}$ On the more formal side, lawyers lobbied the legislature, testifying before committees and promoting the adoption of preferred statutory language within bills. ${ }^{49}$ On the grassroots side, boycotts, pickets, and marches were often used hand-in-hand with litigation. ${ }^{50}$

Soon after McCann's book came out, two other highly regarded scholars embarked on a large-scale project to focus on the workings of what they called "cause lawyers." For years, Professors Austin Sarat and Stuart Scheingold had individually studied different dimensions of the legal profession. ${ }^{51}$ In 1994 they teamed up to organize a conference in Amherst, Massachusetts, to examine lawyers who intentionally challenged the legal professionalism norm, who viewed clients as instrumental for pursuing larger social and political goals, and who attempted to embody the causes that they represented. ${ }^{52}$ Sarat and Scheingold recognized that such lawyers could be "protean and heterogeneous" 53 and could also be found on the right, center, and left of the political spectrum. (In fact, for this reason Sarat and Scheingold purposely eschew what they consider the more restrictive term "public interest lawyer," which they suggest often

the Professional, 5 1NT'L Legal Prof. 209 (1998); Susan Sterett, Caring About Individual Cases. Immigration Lawyering in Britain, in SARAT \& SCHEINGOLd 1998, supra, at 293. Sterett's valuable study of immigrants in Britain notes that lawyers working with the South Asian community recognize that winning immigration cases in court is rare. Yet these lawyers have not abandoned this tactic, namely because "litigation can be a way of gaining public time. Cases can be part of an effort to elevate an issue to the political agenda, occupying time in Parliament and the newspapers." Sterett, in Sarat \& Scheingold 1998, supra, at 310; see also Susan Bibler Coutin, Cause Lawyering in the Shadow of the State: A U.S. Immigration Example, in SARAT \& SCHEINGOLd 2001, supra note 13, at 117.

48. McCann \& Silverstein, in SARAT \& SCheingold 1998, supra note 7, at 267

49. See MCCANn, Rights, supra note 7; Jayanth K. Krishnan, New Politics, Public Interest Groups, and Legal Strategies in the United States and Beyond (200I) (unpublished Ph.D. dissertation, University of Wisconsin-Madison). For a more general set of works that discusses how various tactics are used by group leaders, see Jeffrey M. Berry, Lobrying for the People: The Political Behavior of Public Interest Groups 212-52 (1977); John P. Heinz et al., The Hollow Core: Private Interests in National Policy Making 65 (1993); Kay Lehman Schlozman \& John T. Tierney, Organized InTEREsts AND AMERICAN Democracy 150 (1986); Thomas L. Gais \& Jack L. Walker, Jr., Pathways to Influence in American Politics, in MOBILIZING INTEREST Groups IN AMErica 103, 104-1 I (Jack L. Walker, Jr. ed., 199I); Anthony J. Nownes \& Patricia Freeman, Interest Group Activity in the States, 60 J. PoL'Y 86, 88, 92 (1998).

50. MCCANN, RIGHTS, supra note 7. This point has also been made by others. See CHARLES R. Epp, The Rights Revolution: Lawyers, activists, and Supreme Courts in Comparative PERSPECTIVE 3-8 (1998) (noting that for a litigation strategy and legal mobilization overall to retain sustenance, there has to be pressure from below in the form of various grassroots advocacy tactics,); Frank J. Sorauf, The Wall of Separation: The Constitutional Politics of Church and STATE 42 (1976); Jayanth K. Krishnan \& Kevin R. den Dulk, So Help Me God, 30 GA. J. 1NT'L \& CомP. L. 233, 239-48 (2002) (noting that the "ideas" and tactics from bottom-up grassroots activists helped mobilize religious legal mobilization in the United States, India, and Israel).

5I. For a select sample of works, see SARAT \& ScheINGOLd 1998, supra note 7; Austin Sarat, Law's Two Lives: Humanist Visions and Professional Education, 5 Yale J.L. \& Human. 201 (1993); Scheingold \& Bloom, supra note 47.

52. See SCHEINGOLd \& SARAT 2004, supra note 18

53. Id. at 4 . 
connotes a general welfare, non-partisan type of lawyering.) Despite such variation, Sarat and Scheingold have argued consistently that "recurrent themes and patterns" 54 exist among these professionals that make studying them both empirically and theoretically worthwhile.

For example, Sarat and Scheingold believe that cause lawyers, unlike more detached conventional lawyers, view their lawyering as the representation or manifestation of their own personal, moral, political, and professional values. ${ }^{55}$ According to this view, cause lawyers are partisan; their passion for pursuing changes that affect public policy make them political as well as legal actors. ${ }^{56}$ In other words, cause lawyers use the law to help redistribute power within their communities. ${ }^{57}$ By employing legal discourse and "rights-talk" 58 - as well as various forms of political actionthey seek to crystallize their constituents' aspirations and to affect how, and to what degree, political mobilization occurs. ${ }^{59}$ As Sarat and Scheingold suggest, "cause lawyers have something to believe in and bring their beliefs to bear in their work lives."

\section{B. Opportunities for and Constraints on Cause Lawyering}

Since that first conference in Amherst over a decade ago, Sarat and Scheingold have led this burgeoning field of scholarship as co-authors of numerous articles on cause lawyering and as co-editors of volumes of essays. ${ }^{61}$ Their recent and arguably most important work on this subject, Something to Believe In (2004), culminates years of research on U.S. cause lawyers. In the United States, they argue, the legal profession, law schools, legal practice setting, and political environment are spheres in which cause lawyering manifests itself and encounters both opportunities and constraints. $^{62}$

54. Id. at 5 .

55. Id.

56. Id. at $2-4$.

57. Id. at 9 (noting that "[c]ause lawyers tend to transform the nature of legal advocacybeeoming advocates not only, or primarily, for their clients but for causes and, one might say, for their own beliefs. In thus reversing the priorities of the organized legal profession and in staking out the moral high ground, cause lawyers challenge their professional community.").

58. See, e.g., Richard Abel, Speaking Law to Power: Occasions for Cause Lawyering, in SARAT \& SCHEINGOLD I998, supra note 7, at 69. For an overview and subsequent critique of this point, see GLENDON, supra note 40.

59. As McCann \& Silverstein observe, cause lawyers focus on political mobilization, in particular, because they are often "highly circumspect, critical, and strategically sophisticated about the pitfalls of legal action, the 'liberal' biases of legal norms, and the imperatives of effective political struggle." McCann \& Silverstein, in SARAT \& SCHEINGOLd 1998, supra note 7, at 266.

60. Scheingold \& Sarat 2004, supra note I8, at 2.

6I. Another volume is also on the way this year, dealing with the issue of cause lawyers and social movements. See SARAT \& ScheINGold 2006, supra note I7.

62. See Scheingold \& SARAT 2004, supra note 18. 
First, in terms of the legal profession, indeed the norm that a lawyer must maintain a certain distance from her client's values or the causes associated with her client's case continues to loom. ${ }^{63}$ But according to Sarat and Scheingold, given the bar's current low standing among the general population, the public sentiment that lawyers too often fail to "do good" has, to a certain extent, forced the relaxation of this conventional norm. ${ }^{64}$ The profession's standard-bearers today thus encourage lawyers to pursue cause-lawyering opportunities, which might enhance the profession's public image. ${ }^{65}$ As Sarat and Scheingold explain, though, the profession is quick to constrain those whose cause-lawyering activities begin to undermine either the bar or the bar's general vision of how concepts such as justice, rights, and equality are defined. ${ }^{66}$

Law schools also offer a combination of opportunities and constraints to cause lawyering. ${ }^{67}$ Most law schools proudly proclaim that thcir institutions exist in large part to produce lawyers who will serve the needs of society. Students with visions of making the world a more just and egalitarian place often find their law school clinics to be havens for putting "law-intoaction." ${ }^{68}$ However, as Sarat and Scheingold describe, much of the rest of law school runs in stark contrast to such cause-lawyering ideals. Gcnerally, law school curriculum and pedagogy tend to emphasize the importance of traditional, conventional lawyering skills. ${ }^{69}$ Where cause-lawyering activity exists, it does so at the margins - in the one or two clinical courses students take or within more outright political organizations on campus. ${ }^{70}$

The legal practice setting is a third forum where cause lawyering experiences both opportunities and constraints. ${ }^{71}$ According to Sarat and

63. See id. ch. 2; see also Simon, supra note 42.

64. See SCHEInGold \& SARAT 2004, supra note 18, at 40-44.

65. See id. ch. 2 .

66. Id. at 49 (noting that "[t]he profession accommodates lawyers who construct their practices around the goals of serving causes and targeting clients whose cases further causes which the lawyers favor-at least so long as those causes act within the domain of liberal-legality."). Such causclawyering activity typically involves ensuring procedural justice rather than creating new rights or subverting conventions upon which the bar itself is based.

67. See id. ch. 3.

68. This phrase has become quite well-known among those who study lcgal education. It comcs from the University of Wisconsin Law School, and according to the institution, it means a "belief that law must be studied in action as it relates to society, and not in isolation. [Wisconsin's] legal tradition is a strong part of who we are. The Law School focuses on helping its students understand how law both affects and is affected by every other institutional force in society." University of Wisconsin Law School, Information for Prospective Students, http://www.law.wisc.edu/prospective/action.htm (last visited Nov. 5, 2005).

69. See Scheingold \& SaRat 2004, supra note 18, at 53-54 (noting that "to fully appreciate the tensions and ambivalent relationship between cause-lawyering and the professional project of the organized bar, it is necessary to understand law school's powerful socializing messages-privileging private practice in general and elite law firms in particular and privileging, as well, analytic distance rather than political commitment.").

70. See id. at 67-69.

71. See id. ch. 4. 
Scheingold, there is a continuum. At one end, only limited cause lawyering occurs within certain settings, such as corporate law firms. ${ }^{72}$ Although there are incentives to engage in cause lawyering (such as receiving positive publicity), the structure of this work environment tends to constrain cause lawyering to narrow issues that do not jeopardize firm profits or conflict with wealthy client interests. ${ }^{73}$

Toward the middle of the continuum is what Sarat and Scheingold call "salaried attorneys," who typically work in public agencies or for nongovernmental organizations. By not having to worry about generating fees from clients or working grueling corporate hours, salaried lawyers can focus on advocating for causes in which they believe, legally and politically. ${ }^{74}$ But even with this relative flexibility, salaried lawyers are constrained by several factors, including their own personal politics that sometimes conflict with their required duties, institutional rules within their job setting that limit their options, and the availability of outside resources to fund their employment positions. ${ }^{75}$

At the other end of the continuum are cause lawyers who work in small firms. Lawyers in this setting usually share the same ideological commitments, allowing them to engage in relatively more active cause lawyering than their counterparts. ${ }^{76}$ Yet given the competition within the legal market, these small-firm lawyers still are required to pay close attention to the financial bottom line, which makes their practice and ultimately their cause-lawyering activities less stable. ${ }^{77}$

72. Id. This idea of a continuum draws on an article Scheingold published in 1998 with Anne Bloom. They refer to cause lawyering behavior as falling on a continuum of "transgressiveness." Transgressiveness, for Scheingold and Bloom, has a very specific meaning. That is, the "professional standards of legal practice" - espccially the standard emphasizing the "professional" role the lawyer is to play vis-à-vis her client-are pushed to their limits and beyond by the cause lawyer. See Scheingold \& Bloom, supra note 47, at 212 . Yet transgressive cause lawyering has different gradations, and as Scheingold and Bloom note, its manifestation "varies widely among cause lawyers." $I d$. at 213 . Other factors matter, too, such as political ethos, market for legal serviees, and personal motivations. Note that others also have observed how motivations affect cause lawyers' behavior. See, e.g., HANDLER, supra note 8; Austin Sarat, Between (the Presence of) Violence and (the Possibility of) Justice: Lawyering Against Capital Punishment, in SARAT \& SCHEINGOLD 1998, supra note 7, at 317; Menkel-Meadow, in SARAT \& SChEINGold 1998, supra note 7, at 31; Ronen Shamir \& Sara Chinski, Destruction of Houses and Construction of a Cause: Lawyers and Bedouins in the Israeli Courts, in SARAT \& SCHEINGOLD 1998, supra note 7, at 227. Research by den Dulk highlights how motivations and ideology shape strategies not just of traditionally studied liberal cause lawyers, but of right-wing, religious lawyers as well. See Ann Southworth, Conservative Lawyers and the Contest over the Meaning of "Public Interest Law", 52 UCLA L. Rev. 1223 (2005); den Dulk, Prophets in Caesar's Court, supra note 45.

73. See Scheingold \& SaRAT 2004, supra note 18 , at 74-80.

74. Id. at 80-88; see also Scheingold \& Bloom, supra note 47, at 235-36.

75. SCHEINGOLD \& SARAT 2004, supra note 18, at 80-88.

76. See ScheIngold \& SaRAT 2004, supra note 18, at 88-97.

77. Id. Note that, as Schcingold and Bloom show, prioritizing economic considerations, on occasion, also means having to decline more open-ended, riskier cases that the small-firm lawyer may believe are socially worthy or politically exciting. Scheingold \& Bloom, supra note 47 , at 246 . For 
The final platform in which cause lawyering can emerge-the democratic political environment-is conceptually broader than the venues discussed above. For Sarat and Scheingold, cause lawyers who value, respect, and believe in adhering to the current rules of the democratic process tend to be more successful in their advocacy than those who pursue more "transformative agendas." 78 When working on behalf of their constituents, all cause lawyers, to one extent or another, attempt to extract concessions from those they are challenging. ${ }^{79}$ But how this extraction occurs will determine whether the cause lawyer is part of mainstream political advocacy or on the margins. ${ }^{80}$ Cause lawyers who are able to employ democratically acceptable techniques to fight their cause-such as engaging in constitutional litigation ${ }^{81}$ - are more likely to see their positions validated by those in power, compared to cause lawyers who use extralegal tactics to mobilize "against the law and against the grain of mainstream politics."

Sarat and Scheingold end their book by briefly reviewing the literature on cause-lawyering behavior in other parts of the world and then discussing the challenges many of these advocates face, particularly in nondemocratic societies. Without question, Sarat and Scheingold have made a significant contribution to our understanding of this dimension of the legal profession. But what happens when we look at how other actors-who, until now, have received only limited attention-affect cause-lawyering behavior? By examining three separate movements in the country of India, I explain in the next Part how grassroots leaders can not only serve as the driving force behind what cause lawyers do generally, but also how these activists can shape the "bedrock of cause lawyering"83 strategiesconstitutional litigation.

many small-firm lawyers who enter this career with hopes of transforming the legal system, such dreams confront the economic, political, and emotional hardships that accompany this type of practice. Ambitions of making widespread change are replaced by goals of helping those on an individual, caseby-case level. A rich set of data supports Scheingold and Bloom's assertion that practice site and lawyer motivations affect transgressiveness. The authors are sensitive to the variations within each of these work areas. Not all small-firm cause lawyers act in a highly transgressive manner; likewise, not all corporate cause lawyers are shackled to the norms that govern their practices. Furthermore, they emphasize that their model is not static, nor is their classification scheme mutually exclusive. Their continuum simply illustrates general patterns that they hope move us toward a more comprehensive theory of cause-lawyering behavior.

78. SCHEINGOLD \& SARAT 2004, supra note 18, at 103.

79. For a discussion of this point, see MCCANN, Rights, supra note 7, at 168-70.

80. See SCHEINGold \& SaRAT 2004, supra note 18 , ch. 5 .

81. See $i d$. at 130 (noting that mainstream tactics like constitutional litigation offer "institutional access, legitimacy, and bargaining leverage [to the cause lawyer, whereas] ... those who challenge core premises of liberal democracy-irrespective of whether the challenge comes from the left or the right-are generally deprived of the opportunities afforded by constitutional litigation").

82. SChEINGOLd \& SARAT 2004, supra note 18, at 131 .

83. Id. at 130. 
III

\section{Influencing Constitutional Claim-Making From the Bottom Up}

\section{A. Cause Lawyers, Grassroots Organizers, and Constitutional Litigation in India: Setting the Stage}

Cause lawyers, as we have seen, engage in a variety of legal and political techniques when pursuing their mission. With that said, however, even Sarat and Scheingold recognize that many cause lawyers advocate through the method they know best-constitutional litigation. ${ }^{84}$ It is true that constraints accompany constitutional litigation. Pursuing such a tactic can take years before those seeking redress are granted rewards. In addition, unless the constitutional lawyering is done on a pro bono basis, this tactic can be expensive. And there is always the question of whether even after a favorable constitutional ruling, real-life change will occur at the grassroots level. But constitutional litigation does offer a set of important opportunities as well. Along with allowing the cause lawyer to exhibit her skills and passion for an issue in the public courtroom, "constitutional litigation provides institutional access, legitimacy, and bargaining leverage." ${ }^{85}$ Constitutional litigation tends to be a prestigious form of legal practice, and although it can rattle both the bar and government officials when it seeks to alter the status quo, it retains acceptance as a valid form of political advocacy within the United States.

For the remainder of this study, 1 will explore the use of constitutional litigation by cause lawyers within another democratic context-India. India is a useful case for observers of U.S. cause lawyering, because India and the United States share a number of similarities. Both countries are constitutional democracies; in fact, the Indian Constitution, although much longer in length, draws on principles within the U.S. Constitution. ${ }^{86}$ Both countries also have strong bar associations ${ }^{87}$ and well-respected Supreme Courts that possess the power of judicial review. ${ }^{88}$ (It is also not uncommon for the Indian Supreme Court to follow an American judicial approach to issues of civil rights and civil liberties. ${ }^{89}$ ) In addition, for over fifty years U.S. lawyers and judges have frequently interacted with their Indian counterparts, exchanging ideas on topics that include legal education, alternative dispute resolution, and constitutional jurisprudence, just to name a

84. $I d$.

85. Id.

86. See EPP, supra note 50, at 77.

87. For one example of how strong the Indian bar association is, see Jayanth K. Krishnan, Social Policy Advocacy and the Role of the Courts in India, 21 AM. AsIAN Rev. 91, 121 (2003).

88. See EPP, supra note 50, at 80-81; Gary Jeffrey Jacobsohn, Three Models of Secular Constitutional Development: India, Israel, and the United States, 10 Stud. AM. Pol. Dev. 1 (1996).

89. See, e.g., S.P. SATHE, Judicial Activism in India 12, 19, 122-23 (2002). 
few. ${ }^{90}$ And both countries have witnessed a growth in cause-oriented grassroots movements, with the Indian mobilization notably occurring in the post-colonial era, after the end of Prime Minister Indira Gandhi's Emergency Rule in $1977 .^{91}$

The similarity most important for our analysis, however, is that, as in the United States, there are those Indian cause lawyers who routinely rely on constitutional litigation as the key vehicle for advocating social change. Generally under-analyzed in both settings, though, are the conditions under which cause Iawyers draw upon constitutional language and rhetoric to translate the struggles facing those they represent into recognizable claims that courts can handIe. One often assumes that cause lawyers - as the legal experts most familiar with the judicial process-unilaterally decide how and when to craft such arguments.

Yet, as I will show, leaders at the grassroots frequently help paint the full picture for their cause Iawyers as these Iawyers work to recast what can be life-or-death problems into constitutionally acceptable language. This proposition draws on the most recent scholarship on cause lawyering, which itself has been influenced by the broader, theoretical scholarship on social-movement mobilization. ${ }^{92}$ For example, in his work on the Christian evangelical movement in the United States, Kevin den Dulk shows how grassroots religious leaders have used their "intellectual resources ... [to] generate and shape the[ir] attorneys' motivations and tactics." ${ }^{93}$ Thomas Hilbink, in his historiography of the civil rights movement, highlights how grassroots activists helped provide "visions" to their lawyers championing racial equality both in the courts and in the political sphere. ${ }^{94}$ And there

90. See Jayanth K. Krishnan, Professor Kingsfield Goes to Delhi: American Academics, the Ford Foundation, and the Development of Legal Education in India, 46 AM. J. LEGAL HIST. 447 (2005).

91. See Epp, supra note 50, at 76, 83-85.

92. For a selected sample of the social-movement literature that is referenced in current causelawyering scholarship, see Doug Mcadam et al., Comparative Perspectives on Social Movements: Political Opportunities, Mobilizing Structures, and Cultural Framings (1996); Doug Mcadam, Freedom Summer (1988); Doug mcadam, Political Process and the Development OF BLACK INSURgenCy: I930-I 970 (1982); John D. MCCARThy \& MAYER N. ZaLD, The Trend of Social Movements in America: Professionalization and Resource Mobilization (1973); Sidney Tarrow, Power in Movement: Social Movements, Collective ACtION, AND Politics (1994); Nick Hopkins \& Steve Reicher, Social Movement Rhetoric and the Social Psychology of Collective Action: A Case Study of Anti-Abortion Mobilization, 50 HuM. REL. 261 (1997); Doug McAdam et al., Social Movements, in HandbooK of Sociology 695 (Neil J. Smelser ed., 1988); Doug McAdam \& Ronnelle Paulsen, Specifying the Relationship Between Social Ties and Activism, 99 AM. J. Soc. 640 (1993); John D. McCarthy \& Mayer N. Zald, Resource Mobilization and Social Movements: A Partial Theory, 82 AM. J. Soc. 1212 (1977); Aldon D. Morris \& Suzanne Staggenborg, Leadership in Social Movements, in The Blackwell Companion to Social MOVEMENTs (David. A. Snow et al. eds., 2004).

93. Den Dulk, supra note 45.

94. See Hilbink, supra note 17. Elsewhere, Hilbink also discusses lawyering on behalf of a causeoriented movement as the product of pressure from and influence by grassroots activists. See Thomas M. Hilbink, You Know the Type ... . Categories of Cause Lawyering, 29 LAW \& Soc. INQUIRY 657 (2004). 
have been other scholars who have discussed how "activists work to collectively frame the cause"95 for their lawyers, including studies by Jones, ${ }^{96}$ Shamir and Chinski, ${ }^{97}$ Barclay and Fisher, ${ }^{98}$ Marshall, ${ }^{99}$ and others. ${ }^{100}$ Ultimately, all these observations suggest that the lawyering done on behalf of those at the grassroots is not an isolated endeavor. Instead, cause lawyering is found to be contextual/situational and dependent upon existing opportunities, resources, and frames. ${ }^{101}$ In addition, it can be a cooperative, interactive enterprise between those doing the formal representing and those being represented.

Before proceeding, I highlight two additional points. Notwithstanding the above-mentioned similarities between India and the United States, one important difference lies in the structures of the two systems' legal professions. Bccause of its unique constitutional/legal structure, any cause lawyering that occurs in India tends to be more the exception than the rule. For most Indian lawyers, negotiating, strategizing, fostering a shared understanding of the law, advising, and participating in political activism are generally tasks that are left to others. ${ }^{102}$ Most also do not work at mobilizing or nurturing social movements. ${ }^{103}$ Indian lawyers typically become involved in causes late in the game, and their ties to clients and activists are fleeting. ${ }^{104}$ This is because most are atomistic, solo practitioners who deal

95. See Jones, supra note 17.

96. Id. (arguing forcefully that cause-lawyering scholars should consider how social-movement theorists for years have discussed the "opportunity structures" that grassroots activists provide for lawyers).

97. See Shamir \& Chinski, supra note 72.

98. See Scott Barclay \& Shauna Fisher, Cause Lawyers and Social Movements, Failure and Success: Comparing the Two Waves of Same Sex Marriage Litigation, in SARAT \& ScheINGold 2006, supra note 17 (noting how the activism of social movements helped spur cause lawyers to argue for same-sex marriage rights in Washington state and elsewhere).

99. See Marshall, in SARAT \& SCHEINGOld 2006, supra note 17 (noting how environmentaljustice activists push cause lawyers to realize that policy initiatives need to be directed toward the general public, rather than the elites).

100. In his rich essay discussing the intersection bctwcen cause lawyering and grassroots activism, Thomas Hilbink refers to other studies that also underscore how lawyers can be affected and influenced by a movement. See Hilbink, You Know the Type, supra note 94, at 681-88. For a selected sample of the studies to which Hilbink refers, see Coutin, supra note 47; Lisa Hajjar, From the Fight for Legal Rights to the Promotion of Human Rights: Israeli and Palestinian Cause Lawyers in the Trenches of Globalization, in SARAT \& SCHEINGOLD 2001, supra note 13, at 68; John Kilwein, Still Trying: Cause Lawyering for the Poor and Disadvantaged in Pittsburgh, Pennsylvania, in SARAT \& SCHEINGOLD 1998, supra note 7, at 181; Stephen Meili, Cause Lawyers and Social Movements: $A$ Comparative Perspective on Democratic Change in Argentina and Brazil, in SaRAT \& ScheIngold 1998, supra, at 487; Shamir \& Chinski, supra note 72.

101. For a discussion of these points, see Michael McCann \& Jeffrey Dudas, Backlash: Mapping the Changing Context of Movement Lawyering, in SARAT \& SCHEINGOLD 2006, supra note 17.

102. This point was made several years back by Marc Galanter. Mare Galanter, New Patterns of Legal Services in India, in LAW AND SocieTY IN MODERN INDIA 279 (1989); see also Marc Galanter, Fifty Years On, in SUPREME BUT NOT INFALLIBLE 57 (B.N. Kirpal et al. eds., 2000).

103. Supra note 102.

104. Id. 
with clients, cases, and causes in a discrete, isolated fashion. Rarely are there long-term objectives vis-à-vis clients. ${ }^{105}$ Furthermore, because individuals and groups interested in cause-oriented issues tend to lack resources and high levels of organization, they do not provide a market for lawyers who otherwise may wish to help but are unable to because of their own constraints.

Another problem is that the institutional structure of the Indian courts is more conducive to abuse than to cause lawyering. Procedural laws allow opposing counsel to submit endless interlocutory appeals, resulting in massive delays in judgments and vast backlogs in cases. ${ }^{106}$ Because these opposition lawyers are traditionally paid per court appearance, they have little incentive to resolve cases with cause lawyers in a timely fashion. ${ }^{107}$ Opposition lawyers become masters in the art of perpetuation and manipulate procedural rules to delay cases for decades. ${ }^{108}$

Thus, the conditions seem far from ripe for any type of cause lawyering-let alone constitutional cause lawyering-to exist in India. But despite these unfavorable conditions, some lawyers have been able to act as constitutional cause lawyers, primarily in the upper courts. ${ }^{109}$

In the next Section, I discuss how the Indian Constitution, and the Supreme Court's interpretation of it, has facilitated such "claimmaking." 110 After 1977, the Supreme Court provided greater opportunities for lawyers who practice in these upper courts to draw upon the language

105. Id.

106. In 2002, the Indian Civil Procedure Code was overhauled, with the intent to reduce the number of these types of appeals. It is uncertain whether such a change will make a substantive difference in how the system operates. See Speedier Justice Becomes Reality, TimEs (Chandigarh) July I, 2002, http://www.tribuneindia.com/2002/20020702/nation.htm.

107. Id.; see also Marc Galanter \& Jayanth K. Krishnan, "Bread for the Poor": Access to Justice and the Rights of the Needy in India, 55 HASTINGs L.J. 789 (2004).

108. Galanter \& Krishnan, supra note 107. years ago, a well-known story told in The New York Times detailed a relatively simple property dispute between two neighbors that began in 196I and ended after thirty-nine years of litigation. Apparently a milkman had built a wall with two drains that leaked into a meat cutter's yard. The meat cutter had won a judgment in 1961 that declared the drains illegal, but because of the inordinate number of appeals allowed by the Indian legal process, the case remained open for almost four decades-long after both parties were dead! See Barry Bearak, In India, the Wheels of Justice Hardly Move, N.Y. TimEs, June I, 2000, at Al. Notc that government lawyers, as well, can intentionally delay the process, particularly in cascs where the government is seeking to postpone a final outcome in a case where it is being sued.

109. In India, most lawyers practice exclusively in one of three settings: a lower-level district court, a state High Court, or the Supreme Court. A number of factors determines where one practices. For example, upon graduation from law school, an Indian lawyer interested in practicing usually will take up an apprenticeship with an experienced lawyer who practices in one of three courts. Where that law graduate starts will depend on several variables, including law school performance, geographic location, personal ambition, connections, caste ties, and the like. Commonly, the court where the law graduate apprentices will be the court in which she practices as a lawyer until she retires.

110. This term is a spinoff from the famous article by William L.F. Felstiner, Richard L. Abel \& Austin Sarat, The Emergence and Transformation of Disputes: Naming, Blaming, Claiming ..., 15 LAW \& Soc'y REv. 631 (1981). 
of the Constitution of India to promote cause-oriented agendas. ${ }^{111}$ Following this discussion, I focus on how Indian cause lawyers have engaged in struggles for women's rights, civil liberties, and the environment. In particular, I examine how the active aid of grassroots leaders has enabled cause lawyers to recast the immediate legal needs of individuals into broad arguments for the affirmative enforcement of constitutional rights.

\section{B. The Indian Constitution: A Rhetorical Resource for Mobilization}

On January 26, 1950, India's Constitution "came into force"112 as the supreme law of the newly independent nation-state. Touted as one of the most detailed documents of its kind, ${ }^{113}$ the lndian Constitution sought to guarantee integrity and respect for every Indian citizen, to alleviate the social and economic ills of the past, and to establish representative governing institutions. ${ }^{114}$ Today, the Constitution has twenty-two parts, twenty-plus chapters, nearly four hundred separate articles, a detailed appendix (known as the section of schedules), and a set of directive, nonjusticiable public policy principles. ${ }^{115}$ Embedded as well are the "fundamental rights" guaranteed to every 1ndian. These fundamental rights include the right to equality, the right to freedom, the right against exploitation, the right to practice one's religion, cultural and economic rights, the right to private property, and the right to constitutional remedies. ${ }^{16}$

These fundamental rights enable lawyers to advocate issues in court such as women's rights, civil liberties, and environmental rights. In a moment, I will explain precisely how lawyers have used these fundamental rights to advance such agendas. Before doing so, it is important to note that until about 1977, Indian courts heard very few of these types of cases. According to the Indian constitutional law scholar S.P. Sathe, the pre-1977 "clientele" of the courts mainly included landlords fighting governmental land reform initiatives, industrialists opposing nationalization efforts, and citizens complaining about the lack of governmental services. ${ }^{117}$ As Sathe contends, during this period India lacked a public interest legal culture and

111. As we will see in the next Section, and as the Court has held over the years, the constitution of India is a document lined with deep social-justice and public-policy values. For a discussion of this point, see Granville Austin, The Indian Constitution: Cornerstone of a Nation (1966); Epp, supra note 50; Gary JefFrey JaCoBsohn, The WheEl of LaW: INDIA's Secularism in Comparative Constitutional Context (2003); A.G. Noorani, Constitutional Questions in INDIA (2000); SATHE, supra note 89.

I12. P.M. BAKSHI, The Constitution OF INdia 19 (1998).

113. Id

114. See Austin, supra note 111 .

115. See India Const.; BaKshI, supra note 112.

116. INDIA CONST. pt. III; Jacobsohn, supra note 88.

117. See SATHE, supra note 89. 
as such most cases litigated did not involve women's rights, environmental rights, or civil liberties. ${ }^{118}$

Why, then, did Indian courts see an increase in constitutional claims made on these fronts after I977? One frequent argument is that the end of Prime Minister Indira Gandhi's Emergency Rule in the same year provided the "watershed [moment] in Indian politics.... [when] intellectuals and political leaders began looking to the courts, particularly the Supreme Court, for a means of checking the power of the state."119 During the Emergency period, which lasted from 1975 to 1977 , Mrs. Gandhi ruled by decree, arguing that the state faced a national security threat from opposition forces in the country. ${ }^{120}$ She imprisoned thousands of political foes, suspended the fundamental rights of the Constitution, and pushed into law the forty-second amendment, which barred judicial review of parliamentary changes to the Constitution. ${ }^{121}$ The Supreme Court caved to many of Mrs. Gandhi's demands between 1975 and 1977. With the restoration of democratic rule, however, the Court quickly tried to repair its reputation by appointing commissions to investigate human rights abuses; enlarging public access to legal representation; implementing an "epistolary jurisdiction" in which judges affirmatively responded to grievances petitioned by third parties, letters, or independent news reports; and, perhaps most importantly, relaxing standing requirements. ${ }^{122}$

118. See id. at 52-62. Sathe notes that a public-interest culture failed to thrive during the first three decades of Indian independence because India's democracy had not yet fully consolidated. Disputes over what type of power different governing institutions would hold were frequent. In 1967, for example, the Supreme Court ruled that no institution, including the Parliamcnt, could alter or abridge the fundamental rights of the Constitution. See Nath v. Punjab, A.I.R. 1967 S.C. 1643, 1644. Although it reversed this decision some six years later, the Court still held in the subsequent case that the Constitution had a basic structure to it-exemplified by the fundamental rights-with which no institution could tamper. Kesavananda v. Kerala, A.1.R. 1973 S.C. 1461. Such lack of democratic institutional consolidation seems, according to Sathe, to account for why public-interest advocacy had trouble finding receptive governmental outlets.

119. EPP, supra note 50, at 76.

120. Grassroots activists remained skeptical. They cited several self-interested factors that caused her to suspend the constitution: the economy was weak; the public disapproved of her policies, leading to opposition leaders calling on the military to oust her from power; and she was convicted of corruption charges in a state court in Gujarat. For a discussion of this point and, more generally, lndian political developments following 1947, see Paul Brass, The Politics of India Since Independence (1994).

121. Epp, supra note 50, at 76; see also Granville Austin, Working a Democratic Constitution (2000) [hereinafter Austin, Working].

122. See Carl Baar, Social Action Litigation in India: The Operations and Limitations of the World's Most Active Judiciary, 19 PoL'y STUD. J. 140 (1990); Rajeev Dhavan, Law as Struggle: Public Interest Law in India, 36 J. INDIAN L. INST. 302 (1994); NoORANI, supra note 111. In addition, unlike in the United States, where courts typically hear cases only when issues are "ripe," Indian courts routinely rule on issues that may be "premature." See SATHE, supra note 89, at 198. As early as 1959 , the Supreme Court gave judges the green light to render decisions on issues that may be tangentially related to the case at hand. See Nath v. Comm'r, A.1.R. 1959 S.C. 149. But since the end of the Emergency, the Supreme Court has been less willing to enforce the statute of limitations on even long-delayed claims when it believes that such cases have public or societal ramifications. See, e.g., 
Article 32 of the Indian Constitution guarantees individual standing to petition "for the enforcement of [fundamental] rights conferred by this Part" and authorizes the Supreme Court to issue appropriate orders to enforce those rights. ${ }^{123}$ After 1977, the Supreme Court interpreted article 32 as allowing claimants to petition it directly in matters where the central government allegedly infringed upon their constitutional rights. ${ }^{124}$ In addition, the Court began to read article 226 of the Constitution as giving any claimant alleging a state violation of a fundamental right, or a state violation of a public law statute, standing to file suit in a state high court. ${ }^{125}$ The

Jalmi v. Speaker, (1993) 2 S.C.C. 703. This has been particularly important for individuals advocating on behalf of the above-mentioned issues, as it has given these potential claimants more time to file their cases. Also, since 1977, the Court proudly has engaged in extensive legislative policy making in a variety of public-interest cases. By interpreting as part of its constitutional duties the ability to make policy, the Court has weighed in on an array of public-policy areas, including education, see Kishen $v$. Orissa, A.I.R. 1989 S.C. 677; commercial banking, see Jain v. India, A.I.R. 1990 S.C. 292; health care, see Pullers v. Punjab, A.I.R. 1981 S.C. 14; and, as we will see, other important public-policy areas. The Supreme Court's interpretation of the constitution's "writ jurisdiction" after 1977 also has allowed for more public interest cases to come forward. See, e.g., Morcha v. India, A.I.R. 1984 S.C. 802. Other factors also played a role in the change in constitutional claims' subject matter after 1977. Desai and Muralidhar diseuss how after the Emergency, the ruling government was weak and unable to deal with demands made by public-interest activists. Ashok H. Desai \& S. Muralidhar, Public Interest Litigation: Potential and Problems, in SUPREME BUT NOT INFAllible, supra note 102, at I 59, 162. The courts thus were seen as the best administrative institution to handle such claims. In addition, the "support structure for legal mobilization," for a short while, strengthened in the post-Emergency years. EPP, supra note 50, at 95 . Foreign and domestic funding that supported new, public-interest litigation efforts also increased. $I d$. at 95-103.

123. For further discussion of article 32's grant of standing, see Krishnan \& den Dulk, supra note 50. See also EPP, supra note 50, at 81-82 ("[T]he Indian Supreme Court's jurisdiction is remarkably broad. It has original jurisdiction over disputes between the national government and the states and between different states; it has appellate jurisdiction over criminal and civil cases, ... and it has advisory jurisdiction to render its opinion on any question of law or fact referred to it by the president. The court also has special leave jurisdiction that grants it discretion to hear appeals involving 'any judgment, decree, determination, sentence or order in any cause or matter passed or made by any eourt or tribunal in the territory of India' except for matters relating to the Armed Forces. Thus the Supreme Court may decide nearly any issue that arises in Indian politics.").

124. One of the first cases after the Emergency to highlight this point was Ratlam Mun. Council v. Vardhichand, A.1.R. 1980 S.C. 1622 ("[F]ew profound issues of processual jurisprudence of great strategic significance to our legal system face us and we must zero-in on them as they involve problems of access to justice for the people beyond the blinkered rules of 'standing' of British Indian vintage.") For other cases which followed this same trend, see Wadhwa v. Bihar, A.1.R. 1987 S.C. 579; Gupta v. India, A.I.R. 1982 S.C. 149; People's Union for Democratic Rights v. India, A.I.R. 1982 S.C. 1473; Fertilizer Corp. v. India, A.I.R. 1981 S.C. 344.

125. See, e.g., SATHE, supra note 89 . Article 226 of the Indian Constitution reads:

(1) Notwithstanding anything in Artiele 32, every High Court shall have power, throughout the territories in relation to which it exercises jurisdiction, to issue to any person or authority, including in appropriate cases, any Government, within those territories directions, orders or writs, including writs in the nature of habeas corpus, mandamus, prohibition, quo warranto and certiorari, or any of them, for the enforcement of any of the rights conferred by Part III and for any other purpose.

(2) The power conferred by clause (1) to issue directions, orders or writs to any Goverument, authority or person may also be exercised by any High Court exercising jurisdiction in relation to the territories within which the cause of action, wholly or in part, arises for the exercise of such power, notwithstanding that the seat of such Goverument or 
Court has defined leniently who qualifies as a litigant, without requiring that she specify the relief being sought in order to have her case heard. ${ }^{126}$ And since broadening its locus standi, once the Court has admitted these cases for hearings, it has often gone on to use article 21 -a guarantee that "[n]o person will be deprived of his [or her] life or personal liberty except according to the procedure established by law"-as a mechanism for substantively promoting women's rights, environmental rights, and civil liberties. ${ }^{127}$ That a group of Indian cause lawyers has actively worked with grassroots leaders in championing these types of cases in court is my next focus. ${ }^{128}$

authority or the residencc of such person is not within those territories. (3) Where any party against whom an interim order, whether by way of injunction or stay or in any other manner, is made on, or in any proceedings relating to, a petition under clause (1), without - (a) furnishing to such party copies of such petition and all documents in support of the plea for such interim order; and (b) giving such party an opportunity of being heard, makes an application to the High Court for the vacation of such order and furnishes a copy of such application to the party in whose favour such order has been made or the counsel of such party, the High Court shall dispose of the application within a period of two weeks from the date on which it is received or from the date on which the eopy of such application is so furnished, whichever is later, or where the High Court is closed on the last day of that period, before the expiry of the next day afterwards on whieh the High Court is open; and if the application is not so disposed of, the interim order shall, on the expiry of that period, or, as the ease may be, the expiry of the said next day, stand vacated. (4) The power conferred on a High Court by this article shall not be in derogation of the power conferred on the Supreme Court by elause (2) of Article 32.

INDIA CONST. art. 226.

126. This is the whole point of the "writ petition" referred to above. The idea is that not just lawyers, but ordinary citizens who may not know legalese but who have been aggrieved by the state, should be able to access the courts and have their concems heard by a fair, impartial judiciary.

127. INDIA CONST. art. 21.

128. As stated above and in the previous Part, the focus here is on lawyers who practice in the upper courts. District court lawyers rarely submit artiele 32 petitions to the state High Court or the Supreme Court. In fact, there are restrictions regarding who ean submit sueh claims. If a district court lawyer believes she needs to file an article 32 petition, she usually works with an upper court practitioner to do so. For a host of scholarship on upper court lawyers filing article 32 petitions, see Upendra Baxi, Courage, Craft, and Contention (1985); P.N. Bhagwati, Judieial Activism and Public Interest Litigation, 23 Colum. J. TranSNat'L L. 561 (1985); Jamie Cassels, Judieial Activism and Public Interest Litigation in India: Attempting the Impossible?, 37 AM. J. CoмP. L. 495 (1989); Clark D. Cunningham, Public Interest Litigation in Indian Supreme Court: A Study in the Light of American Experience, 29 J. IndIAN L. INST. 494 (1987); Galanter, New Patterns, supra note 102, at 279-95; N.R. Madhava Menon, Justice Sans Lawyers: Some Indian Experiments, 12 INDIAN BAR REv. 446 (1985); Oliver Mendelsohn, Life and Struggles in the Stone Quarries of India: A Case-Study, 29 J. Commonwealth \& ComP. POL. 43 (1991) [hereinafter, Mendelsohn, Life and Struggles]; G.L. Peiris, Public Interest Litigation in the Indian Subcontinent: Current Dimensions, 40 INT'L \& CoMP. L.Q. 66 (1991); S.P. Sathe, Judicial Activism, 10 J. Indian SCH. POL ECON. 399 (1998); S.P. Sathe, Political Activism (11): Post-Emergency Judicial Activism: Liberty and Good Governance, $10 \mathrm{~J}$. INDIAN Sch. Pol. ECON. 603 (1998); Susan D. Susman, Distant Voices in the Courts of India: Transformation of Standing in Public Interest Litigation, 13 WIS. IN T'L L.J. 58 (1994). 


\section{Constitutional Rhetoric: Transforming Individual Needs into Social Change}

Indian cause lawyers have learned to recast the immediate, material, and often life-or-death demands of grassroots movements into constitutional claims that courts can handle. The evidence supporting my argument comes from two sources. First, I conducted extensive content analysis of the relevant case law where women's rights, civil liberties, or environmental rights were at stake. ${ }^{129}$ These issues represent three of the most typical cause-oriented movements found in India. Second, beginning in the late 1990s and culminating in 2004, I made repeated research visits to India. For this study, I rely on information gathered from eighty-four semistructured interviews-fifteen of which were with judges, forty-one with lawyers, and twenty-eight with grassroots leaders who work on these social policy issues. ${ }^{130}$ These interviews, as I will show, reveal several telling and often quite moving accounts. Out of respect for some respondents' requests for confidentiality, the interview evidence I present below is at best only a snapshot of what is occurring on the ground. However, combining the case law analysis with the fieldwork offers support for understanding the dynamics of grassroots activism on Indian cause lawyers and how these lawyers tend to recast activists' issues.

\section{Cause Lawyering for Women's Rights in India}

With the Constitution's passage in 1950, Indian women received, for the first time, the same legal rights and opportunities as men. Article 15, section 1 of the Indian Constitution proclaims that " $[t]$ he State will not discriminate against any citizen on grounds only of religion, race, caste, sex, place of birth or any of them."131 But because the framers of the

129. The case law on which I draw mainly comes from those matters litigated in the Supreme Court. It should be noted that currently the Court has over 20,000 cases on its docket, and it is believed to be the most crowded of any constitutional court in the world. See Bibek Debroy, Losing a World Record, FAR EASTERN ECONOMIC, Feb. 14, 2002. The docket is further divided between what Epp categorizes as the Court's public law agenda-most of the decisions of which the Court publishes in law reports - and the Court's "routine agenda" consisting of "tens of thousands of unpublished decisions." EpP, supra note 50, at 90. For the most part 1 focus on the former and rely on Sathe, supra note 89 , for comprehensive collection and categorization of these public law cases. Drawing on Sathe's work as well as other Indian constitutional law books, see, for example, AusTiN, Working, supra note 121; BaKshi, supra note 112; D.D. Basu, Constitutional LaW of India (1998); Noorani, supra note 111,1 put together a list of women's rights, civil liberties, and environmental rights cases. Further, 1 used the Indian computerized database Supreme Court Judgments, at http:/www.scjudgments.com, to gather cases not found in these texts. I then read and conducted content analysis of each of these cases. ( 1 also relied on the indexes provided within the case reporters, but because these were sometimes incomplete, I triangulated the information gathered from this source with case cites found within the more scholarly books on constitutional law as well as the Supreme Court Judgments website.)

130. The majority of the interviews took place in the country's capital, New Delhi. However, some interviews also occurred in Mumbai, Bhopal, Hyderabad, and Bangalore.

131. INDIA CONST. art. 15. 
Constitution recognized that section 1 might not be sufficient to protect the rights of women, they included section 3 , which states, "[N]othing in this article [15] shall prevent the State from making any provision for women and children." 132 Courts, in fact, have permitted the government to use section 3 to grant explicit reservations for women in the educational and public employment sectors. ${ }^{133}$

But for the reasons stated above, a mass-scale women's movement did not emerge before 1977. ${ }^{134}$ Although strong groups of women existed in colonial and even pre-colonial times, in the post-colonial era "[i]t was only when the Emergency was lifted, some 18 months later, that . . many of the contemporary women's groups began to get formed, with their members often being women with a history of involvement in other political movements." 135 Not surprisingly, women's organizations soon viewed sympathetic political parties as key allies in the fight for gender equality. ${ }^{136}$ A pronounced sense of rights-based consciousness and empowerment developed, ${ }^{137}$ and advancements in technology and communication enabled more women from different parts of India to share their common problems, challenges, and obstacles. ${ }^{138}$ The new opportunities available to women thus facilitated an exciting exchange of ideas about the various rights to which they were long entitled, including those guaranteed to them under the Constitution. ${ }^{139}$

For good reason, then, these developments might suggest the presence of a large-scale feminist movement in India, similar to the one the United States experienced during the 1970s. But in India, the fight for women's rights, in many ways, has been more plural and, at times, more fragmented than the movement in the United States, often reflecting the struggle for

132. Id.

133. For an early case that discusses the reservations issue, scc Andhra Pradesh v. Sagar, A.l.R. 1968 S.C. 1379. See also Austin, supra note 111; Austin, Working, supra note 121; MARC Galanter, Competing Equalities (1984). Note, during the 1960 s and 1970 s, the number of women with formal education jumped, and with this education came greater exposure to the Constitution's ideals of equality, dignity, and justice. See generally COMMITTEES AND COMMIssions on WOMEN Education (Usha Sharma \& B.M. Sharma eds., 1995); From IndePEndence Towards Freedom 227 (Bharati Ray \& Aparna Basu eds., 1999).

134. In fact, Urvashi Butalia, the cofounder of the Indian feminist publishing house, Kali, has argued that there has not been a single, unified feminist movement but rather one that is strongly plural, albeit at times fragmented. See Urvashi Butalia, The Women's Movement in India: Action and Reflection, THIRD WORLD NETwORK, http://www.twnside.org.sg/title/indial-cn.htm (last visited Nov. 15, 2005).

135. Id.

136. Raka Ray, Fields of Protest: Women's Movements In INdia 13-44 (I999).

137. Ray \& Basu, supra note 133, at 227; Raj Pruthi \& Bela Rani Sharma, Education and MODERNISATION OF WOMEN IN INDIA (1995).

138. Supra note 137.

139. See Anjali Bahuguna, Science and Technology in Relation to Rural Women (1995); Community, Gender and Violence (Partha Chatterjee \& Pradeep Jeganathan eds., 2000); RAY \& BASU, supra note 133. 
basic survival. ${ }^{140}$ While on occasion India's women's groups advocate for broader public policy issues, such as pay equity ${ }^{141}$ much of their work remains focused on issues such as combating arranged marriages for minors, rapes committed by police officers, extortion of dowry from women's families, and even wife-murders, which husbands often conveniently report as "accidental" kitchen fires. ${ }^{142}$ Raka Ray has described how even in progressive cities like Mumbai, Hyderabad, Delhi, and Bangalore, women's groups confront domestic violence, sexual harassment, and lack of access to proper health care. ${ }^{143}$

Given this history, cause lawyers who work with women's organizations realize that before trying to make social change at the governmental level, it is important to engage with and learn from those at the grassroots level. Consider the events that led to the passage of the Criminal Code Amendment of $1983 .{ }^{144}$ In this tragic case, two police officers were accused of raping a tribal girl, Mathura, who was brought in for questioning. The Supreme Court ultimately heard the case and vindicated the officers, ruling that the prosecution had failed to show that the victim had tangibly resisted. ${ }^{145}$

Understandably, the Mathura ruling drew a firestorm of criticism. Various women's groups engaged in publicity campaigns and demonstrations, wrote newspaper editorials, and voiced their concerns to four wellknown cause lawyers in Delhi. In an open letter to the Court's chief justice, the lawyers chastised the decision as one of the most egregious in Indian constitutional jurisprudence. Invoking the constitutional principles of life and liberty, ${ }^{146}$ equal protection,${ }^{147}$ and gender equality, ${ }^{148}$ the lawyers urged the Court, the Parliament, and the public to reexamine the treatment of women in Indian society. ${ }^{149}$ Through its powers under article 32, the

140. See supra note 134.

141. See Ray, supra note 136, at 3-8, 45-62; see also The Equal Remuneration Act, 1976, No. 25, Acts of Parliament, 1976.

142. For a discussion of these "kitchen-fire" deaths, see UN1CEF, The Progress of Nations 1997: Women Commentary, available at $\mathrm{http} / / / \mathrm{www}$.unicef.org/pon97/women lb.htm (last visited Nov. 15, 2005). For additional readings rclevant to this issue, see GaIl OMvedt, VIOLENCE AGalNST Women: New Movements and New Theories in India (1990); Ray \& Basu, supra note 133; Kalpana Roy, Encyclopedia of Violence Against Women and Dowry Deaths in 1NDia (1999).

143. RAY, supra note 136, at 3-4.

144. For an overview of this episode, see Epp, supra note 50, at 105-06.

145. Tukaram v. Maharashtra, A.I.R. 1979 S.C. 185, 189 (noting, shockingly, that "no marks of injury were found on the person of the girl after the incident and their absence goes a long way to indicate that the alleged intercourse was a peaceful affair, and that the story of a stiff resistance having been put up by the girl is all false").

146. See India Const. art. 21.

147. See India Const. art. 14.

148. See InDIA Const. art. 15.

149. See Upendra Baxi et al., Open Letter to the Chief Justice of India, (1979) 4 S.C.C. 17; see also Upendra Baxi, The "Ultimate Violation of Self": Reflections on Judicial Discourse of Attempted Rape, (1998) 6 S.C.C. 1, available at http://www.ebc-india.com/lawyer/articles $/ 98 \mathrm{v} 6 \mathrm{a} 1 . \mathrm{htm}$. 
Supreme Court reheard the case, although it refused to reverse its original decision. ${ }^{150}$ Parliament eventually enacted substantive changes to the Criminal Procedure Code (1983), effectively legislating that if women were to enjoy full liberty and equality in Indian society, courts in the future no longer could rely on the Mathura rationale when rendering a judgment on sexual assault. ${ }^{151}$

The Mathura episode highlights how grassroots pressure enabled cause lawyers to recast a concrete issue of basic security-women suffering rape while in policy custody-into a constitutional claim in order gain the attention of the Court, Parliament, and the public at large. The lawyers' petition helped to start a national dialogue on police abuse and the rights of women in the criminal justice system. In several other high-profile rape cases, grassroots leaders have worked with cause lawyers to press rape claims in court, prompting the development of what one scholar calls the Court's "rape jurisprudence."152.

In Baxi v. State of Uttar Pradesh, for example, law professor Upendra Baxi utilized the Court's broadening of locus standi under article 32 to argue that women in state custody had substantive liberty rights under article 21 to be free from cruel and unusual treatment. ${ }^{153}$ The case involved women who had been convicted of prostitution and were living in a staterun rehabilitation home. ${ }^{154}$ Certain wardens of the home were denying the women food, keeping the women in squalid conditions, and even forcing the women to have sex with them in exchange for basic needs. ${ }^{155}$ Eventually several women in the rehabilitation home related their horrific experiences to advocates like Lotika Sarkar, a leading grassroots women's rights activist, scholar, and lawyer herself. ${ }^{156}$ Sarkar worked together with Professor Baxi in crafting the legal arguments that were eventually presented to the Court. ${ }^{157}$ Ultimately, the Court held that the women in this

150. This opinion was unreported, although the filing of the rehearing petition is noted in Sathe, supra note 89 , at 228 .

151. EPP, supra note 50, at 105-06; K.N. Chandrasekharan Pillai, Women and Criminal Procedure, in Engendering Law: Essays in Honour of Lotika SARKar I6I (Amita Dhanda \& Archana Parashar eds., 1999).

152. SATHE, supra note 89 , at 228.

153. Baxi v. Uttar Pradesh, 1981 Indlaw S.C. 331, para. 1.

154. Id. For a discussion of this case, see Prabha Kotiswaran, Preparing for Civil Disobedience: Indian Sex Workers and the Law, 21 B.C. THIRD WoRLD L.J. 161, 171 n.29 (2001).

155. Id. at 174.

156. In 1999, two scholars put together a festschrift of Sarkar's contributions to the law and to women's rights in India. Professor Baxi was among the contributing essay writers. See ENGENDERING LaW: Essays in Honour of Lotika Sarkar (Amita Dhanda \& Archana Parashar eds., 1999).

157. Baxi, I981 Indlaw S.C. 331; S. Muralidhar, The Case of the Agra Protective Home, in ENGENDERING LAW, supra note 156; see also Kotiswaran, supra note 154, at $171 \mathrm{n} .29$. According to Kotiswaran's moving description,

[C]onditions at an Agra [state-rehabilitation] home instigated two public interest petitions in the Supreme Court of India .... The petitioners contended that while section 21 of the 1956 [Suppression of Immoral Traffic in Women and Girls] Act requires that these protective 
home, as well as all individuals under state care, had a constitutional right to humane treatment. ${ }^{158}$

A few years later, efforts to raise awareness about child prostitution and abduction in New Delhi prompted a women's-rights cause lawyer to petition the Supreme Court for a judgment outlawing female child prostitution. ${ }^{159}$ On the clients' behalf, the lawyer alleged that young girls were being kidnapped and raped in brothels in New Delhi's red light district while police officers looked the other way or were otherwise complicit in the crimes. ${ }^{160}$ Again, grassroots advocates, through the publication of exposés, the interviewing and counseling of victims, and the holding of awareness seminars throughout the city, sought to convey to the Delhi public the grueling conditions under which these children lived. As cited by the Court in its opinion, these activists helped the lawyer both understand and articulate to the justices that without judicial enforcement of the girls' fundamental right to safety, the ban on trafficking in article 23 would be rendered meaningless. ${ }^{161}$ Ultimately the Court recommended that states establish

homes be run effectively, the Agra home could not be run so at the expense of the human rights of its inmates. Many of the female inmates suffered from mental retardation and serious contagious diseases, but did not receive appropriate medical care. In response, the Supreme Court ordcred proper medical care for the prostitute women who were in need of medical attention."

Kotiswaran, supra note 154 , at 171 n.29.

158. Id. The sad facts of this case, however, did not end with this particular Supreme Court judgment. Instead, there was over a decade worth of litigation regarding this matter. For instance, in 1986 Dr. Baxi filed a petition to stay the state's moving of the rehabilitation home to a different location. See Baxi v. Uttar Pradesh, 1986 Indlaw S.C. 744. The Court ultimately refused to enjoin the move, but it set forth spccific orders requiring the home to ensure the health, safety, and welfare of its inhabitants. However in 1996, Dr. Baxi filed a follow-up petition arguing that the rehabilitation home was not performing its statutory duty to ensure that its residents' welfare was protected. The Court ordered the secretary of the department of women and child development of the goverument of Uttar Pradesh to ensure that the residents were humanely treated. See Baxi v. Uttar Pradesh, 1996 Indlaw S.C. 2019. Finally, in 1997 the Court decided to turn over the oversight responsibilities of the group home to the National Human Rights Commission (NHRC), an independent (albeit governmental) body in charge of monitoring human rights abuses in India. According to the Court, the NHRC would be in the best position to supervise the activities inside the home. See Baxi v. Uttar Pradesh, 1997 Indlaw S.C. 1647.

159. Jeet v. India, 1990 Indlaw S.C. 823; see also Kotiswaran, supra note 154. In 1956 India passed the Immoral Traffic Prevention Act (ITPA), which stoppped short of illegalizing prostitution per se but criminalized "all related actions." Kotiswaran, supra note 154 . In the years that followed, the Indian government made varied, inconsistent, and too frequently futile efforts at dealing with the issue of prostitution and to date has not amended the ITPA. Id. Thus, lawyers in Jeet case sought judicial relief to obtain a definitive, sound policy judgment from the Court.

160. Jeet, 1990 Indlaw S.C. 823 , para. 1 .

161. See id. para. 3. As the Court's opinion noted, interviews with victims and advocates provided the substance of the lawyers' arguments:

The petitioner has cited certain lurid tales of sex with the sickening details alleged to have been confessed by somc children and girls either escaped or rescued from the such abodcs of ill-fame. After giving a brief note on Devadasi system and Jogin tradition, the petitioner states that this system and tradition which are still prevailing in some part of the country should be put to an end. The ultimate plea of the petitioner is that the young children and girls forcibly pushed into 'flesh trade' should be rescued and rehabilitated. With this petition, the petitioner 
executive committees to fight child prostitution and ordered the national government's Central Bureau of Investigation (CBI) to study how best to ensure that no child is deprived of life or personal liberty, as provided for by article 21 .

In the infamous "Gajraula nuns case," women's rights groups worked in coalition with India's Christian community to seek relief following the rape of two Christian nuns and the physical assault of five more on their school campus in the state of Uttar Pradesh in $1990 .{ }^{162}$ When the police failed to respond for weeks following the attacks, activists from the two groups began to strategize a litigation path. ${ }^{163}$ In addition to coordinating a temporary, national closure of all Christian educational institutions, holding vigils, condemning the attacks in the press, and peacefully taking to the streets, the coalition decided to petition the Supreme Court. ${ }^{164}$

Violence against Christian communities was not an uncommon occurrence. A leading member of an Indian Christian organization involved in the 1990 mobilization told me some years later that the Christian activists' goal had been to use constitutional rhetoric to convey to their leaders and lawyers that these sorts of violent acts were unacceptable, criminal, and most importantly antithetical to a democratic society. ${ }^{165}$ According to this official, the leaders involved in the movement did end up "getting it,"166 and were, in the words of Shamir and Chinski, "transformed"167 by their

has filed 9 affidavits said to have been sworn by 9 girls who claim to be living in the brothel houses, pleading for rescue and a list of names of 9 girls who are mortally afraid to swear the affidavits.

Id.

162. Cherian v. India, (1992) I S.C.C. 397

165. Kirti Singh litigated the case. Rick Halperin, Death Penalty News-Worldwide (Nov. 2, 1998), http://venus.soci.niu.edu/ archives/ABOLISH/nov98/0026.html. Beyond this particular matter, Singh has written about women's groups' advocacy for legal and constitutional rights:

The post emergency period witnessed intense and widespread movements by women's organisations and groups to bring about law reform to deal with atrocities and violenee against women. The eampaign by women's organisations and those supporting them focused mainly on reform in the laws relating to dowry and rape. Women's organisations during the late 1970 s and early 1980 s demanded from the state that sweeping amendments be introduced in these laws to check the rising tide of crimes against women. Newspaper and media reports had highlighted the fact of young brides being burnt for failure to bring sufficient dowry from 1978 onwards, and these became the focus for struggle by women's organisations who formed forums like the Dahej Virodhi Chetna Manch (DVCM) to launch a united action .... Similarly, reports of rape and sexual assault, particularly by the poliee and others in authority, brought women's organisations and groups together in different cities to press for changes in the laws relating to rape.

Kirti Singh, Women and the Law, Institute of Management and Government Thiruvananthapuram: Training Module on Gender Issues in Development 9l (1995), available at http://persmin.nic.in/otraining/Gender\%20lssues\%20(Reading\%20material).pdf.

164. See id. A website that tracks violence against Christian Indians has reported on this infamous case. See Assaults on Priests and Religious-Acts of Vested Interests?, http://www.geocities.com/ christbugle2000/persec 1.htm (last visited Nov. 17, 2005).

165. Interview with anonymous subject (Dec. 23, 2001).

166. Id.

167. See Shamir \& Chinski, supra note 72. 
experiences with the grassroots. Eventually it was argued in Court that to protect the rights of religious minorities, the Court had to take an institutional lead in the criminal investigation by ordering the CBI to oversee the state police inquiry. ${ }^{168}$ The Court agreed; and, when it learned that the agency had botched the investigation, it directly rendered monetary damages in favor of the victims. ${ }^{169}$

In this series of litigation, grassroots activists worked with cause lawyers to match on-the-ground realities with the larger public-policy implications of positive social change. This symbiotic relationship has prompted other litigation for women's rights. For instance, cause lawyers who work on employment-based sexual harassment cases told me that they routinely consult with activists from two women's organizations before crafting their constitutional arguments. ${ }^{170}$ The respondents mentioned that they were simply following the lessons passed down to them by other lawyers. Those lawyers, in turn, had studied the tactics used by earlier lawyers who had won two important Supreme Court rulings in this area.

In each of the two precedent-setting cases, ${ }^{171}$ the lawyers did not prepare their arguments for court in isolation. Rather, after working closely with social activists and NGOs, the lawyers argued in their respective cases that the state had a duty to protect the individual liberty of every person in the home and on the job. They also argued that the threat of sexual harassment inhibited women from freely expressing themselves and from freely moving within the country ${ }^{172}$-a direct violation of article 19 and the equal protection clause in article 14. The Court admitted the petitions in both cases and ordered broad workplace protections for women. ${ }^{173}$

Of course, just because these cause lawyers worked with grassroots leaders in crafting constitutional arguments does not mean that the Indian Supreme Court necessarily followed suit. That the Court's jurisprudence in this area has tended to embrace the positions argued by these cause lawyers may indeed be the result of attitudinal preferences, strategic decisionmaking, or a combination of these and other reasons. The key point for our purposes is that cause lawyers working on behalf of women's rights do not

168. Cherian v. India (Gudalure 1), (1992) 1 S.C.C. 397, 397 para. 3.

I69. Cherian v. India (Gudalure II), 1995 Indlaw S.C. 1657. Some have argued, though, that the Court issued these damages to divert attention from its inability to effectively run the investigation and to avoid prolonging embarrassment to the state police. For another decision that has received less public skepticism, see Goutam v. Chakraborty, (1996) 1 S.C.C. 490 , wherc the Court held that women under article 21 had a constitutional right to live with dignity, free from the fear of being raped.

I70. Interviews with three such cause lawyers (Aug. 21, 2002).

171. See e.g., Apparel Export Promotion Council v. Chopra, A.I.R. 1999 S.C. 625; Vishaka v. Rajasthan, A.I.R. 1997 S.C.C. 241. For an insightful editorial on this subject, see Forge a Healthy Workplace, THE Hindu, Dee. 21, 2003, available at http://www.hindu.com/thehindw/ $\mathrm{mag} / 2003 / 12 / 21 /$ stories/2003122100130600.htm.

172. See Chopra, A.1.R. 1999 S.C. 625 ; Vishaka, A.I.R. 1997 S.C.C. 241.

173. See Chopra, A.I.R. 1999 S.C. 625 ; Vishaka, A.I.R. 1997 S.C.C. 241. 
pursue constitutional claims in a vacuum. Instead, as we have seen, constitutional litigation can be a tactic that involves the efforts of both those at the grassroots and the lawyers who represent them.

\section{Cause Lawyering for Civil Liberties in India}

Like women's rights lawyers, civil liberties cause lawyers in India have often litigated claims by first working with local activists, then using constitutional rhetoric to recast their constituents' plight into demands that are acceptable to the courts.

For example, in People's Union for Democratic Rights (PUDR) v. Union of India,${ }^{174}$ PUDR lawyers petitioned the Supreme Court on behalf of Delhi-based laborers who were not being paid and were forced to work in decrepit conditions. As the lawyers Iearned from these local workers, this situation was not an isolated incident: manual laborers routinely suffered abuse, non-payment of wages, and worse from their employers. ${ }^{175}$ In what were often frank, emotional meetings, the labor leaders drew on their own experiences and the experiences of others to explain to their lawyers the importance of framing legal arguments broadly, so that if they prevailed in court, manual workers as a class might benefit. ${ }^{176}$

Drawing on this advice, the cause lawyers asked the Supreme Court not only to affirm the existing Payment of Minimum Wage Act, a federal law setting guidelines on both wages and hours, but also to apply article 23 of the Constitution broadly to all workers similarly situated throughout the country. ${ }^{177}$ The Court accepted the petition under its article 32 powers, upheld the federal statute, and, for the first time, ruled that employers who did not pay fair wages and provide humane working conditions to their employees would be found guilty of violating article $23 .{ }^{178}$

Another well-known illustration of grassroots leaders' assisting constitutional claim-making involved a case filed soon after the end of the

174. A.I.R. 1982 S.C. 1473

175. Id: Interview with PUDR Official, in New Delhi, India (July 23, 2003). During this interview, the PUDR official stressed how the legal organization learned an immense amount of information from the workers on labor activity throughout lndia. For a background discussion of this case, see SATHE, supra note 89 , at 205-210.

176. Interview with PUDR Official, supra note 175.

177. PUDR, A.I.R. 1982 S.C. 1473 1NDIA CONST. art. 23 ("Traffic in human beings and begar and other similar forms of forced labour are prohibited and any contraventions of this provision will be an offence punishable in accordance with law.").

178. PUDR, A.I.R. 1982 S.C. 1473. Similarly, in Morcha v. India, 1983 Indlaw SC 192, A.I.R. 1984 S.C. 802, a lawyer working with oppressed bonded laborers in the Fardiabad quarries near Delhi petitioned the Court to enforce the provisions of the Bonded Labour Systcm (Abolition) Act of 1976. The law was a piece of Emergency legislation that statutorily codified the above mentioned article 23. The laborers had completed their project by the time the Court issued its judgment. Still, the ruling adopted the grassroots-inspired, lawyer-driven argument in totem and, furthermore, was "pronounced in the language of outraged morality" toward abusive employers. Id.; see also Mendelsohn, supra note $128,43,69$ n. 3 . 
Emergency. Here, lawyers petitioned the Supreme Court in an effort to end the beatings of prisoners by police officers. ${ }^{179}$ The case was initiated after an inmate, Sunil Batra, wrote directly to Chief Justice Krisha Iyer explaining the horrendous conditions he was enduring in prison. Moved by the letter, the chief justice asked members of the bar to prcpare oral arguments on this matter so that a proper, formal hearing in the Supreme Court could proceed. ${ }^{180}$ Although the lawyers were procedurally familiar with filing constitutional claims, not until they met with and learned from Batra, other prisoners, and prisoners' rights activists did they fully grasp the inmates' perilous living conditions. ${ }^{181}$ In court, the lawyers relayed the prisoners' nightmarish experiences to the justices and crafted arguments around article 21 's principle that incarcerated individuals have a right to live with dignity and to be free from torture. ${ }^{182}$ The Court upheld these arguments,

179. Batra v. Delhi Admin., 1978 Indlaw S.C. 289.

180. In theory, after its expansion of locus standi, the Court has held that other cases involving the public interest may be admitted by way of citizens writing a simple letter. However, as noted by Sathe, supra note 89 , at $205-06$, as the 1980 s proceeded, such "letters to individual judges . . became rare."

181. As Justice Krishna lycr writes in his opinion, Mr. Batra and his lawyer, Y.S. Chitale, together "painted" the "lurid lot" in which Batra lived. As Batra and Chitale described to lyer,

Grim walls glare at him [i.e., Batra] from all sides night and day; his food is inserted into the room and his excretory needs must be fulfilled within the same spacc. No pillow to rest his restless head, no light inside, save the bulb that burns blindly through the night from outside. No human face or voice or view except the warder's constant compulsory intrusion into the prisoner's privacy and the routine revolutions of officials' visitations, punctuated by a few regulated visits of permitted relatives or friends, with iron bars and peering warder's presence in between. No exercise except a generous half hour, morning and evening, in a small, walled enclosure from where he may do asanas were he yogi, do meditation were he sanyasi and practise communion with Nature were he Wordsworth or Whitman or break down in speechless sorrow were he but common clay. A few books, yes; newspapers? No. Talk to others? No, save echoes of onc's own soliloquies; no sight of others except the stone mercy in pathetic fallacy. This segregation, notwithstanding the prescribed category of visitors permitted and censored letters allowed, argues Sri Chitale, is violation of the primordial gregariousness which, from the beginning of the species, has been man's social milieu and so constitutes a psychic trauma, when prolonged beyond years, too torturesome for tears, even in our ancient land of silent mystics and lonely cavemen. For the great few, solitude sometimes is best society but for the commonalty the wages of awesome seculsion, if spread over long spells, is insanity. For the fevered life of the modern man, more so under the stress of sentence, solitude is terror and cellular vacuum horror. Just think not of the contemplative saint but of the run of the mill mortal. Cage his lonely person and monitor his mind and mood with a sensitive understanding. Then you know that moments bear slow malice; hours hang heavy with ennui; days drop dead, and lonely weeks wcar a vicious stillness; for sure, wcary months of singleness, with monotonous nights, made more hurtful by the swarms of mosquitoes singing and stinging, and in many cells, by the bloodthirsty armics of bugs, invisibly emerging from nocturnal nowhere, to hide and bite, make for lunacy. Time cries halt and the victim wonders, is death a better deal? Such is the torture and tension of the solitary cell, picturised by counsel.

Batra v. Delhi Admin., 1978 Indlaw SC 289, A.1.R. 1978 S.C. $1675,1688$. In fact, as a result of working with other abused inmates, other cause lawyers subsequently filed a number of cases against prison officials over the next two decades. See, e.g., Basu v. West Bengal, (1997) 6 S.C.C. 642; Bagga v. Uttar Pradesh, A.I.R. 1995 S.C. 117; Javed v. Maharashtra, A.I.R. 1985 S.C. 231; Singh v. Punjab, A.1.R. 1983 S.C. 465 ; Khatri v. Bihar, A.1.R. 1981 S.C. 928; Khatoon v. Bihar, A.1.R. 1979 S.C. 1360; Ram v. Uttar Pradesh, A.1.R. 1979 S.C. 745.

182. Batra v. Delhi Admin., 1978 Indlaw SC 289, AlR 1978 S.C. 1675. 
noting that the degradation of prisoners was contrary to the fundamental rights guaranteed by the Constitution. ${ }^{183}$

Cause lawyers have employed article 21 in a range of civil liberties litigation to highlight the everyday struggles that confront the disadvantaged. Lawyers have invoked article 21 to gain protection for the homeless on the basis that an individual's right to due process prohibits the state from conducting forced relocations without judicial process. ${ }^{184}$ Article 21 has also been used to advance the rights of the ill, including requiring hospitals to treat the uninsured and poor in emergency cases, ${ }^{185}$ requiring hospitals to have functioning medical equipment, ${ }^{186}$ mandating that patients in mental hospitals be treated with the utmost of care, ${ }^{187}$ and ordering local government enforcement of general public health mandates. ${ }^{188}$

Of course, in all these article 21 cases the specifics of how grassroots activists interact with their cause lawyers vary, but the general theme of interdependence remains. For instance, in the health-related cases, 1 learned that lawyers often held multiple informational meetings with aggrieved patients to strengthen their own understanding of the issues at hand. Capturing the sentiment, one such lawyer noted, "1 play the role of a journalist of sorts. I do a lot of interviewing and fact-gathering so that at least 1 can sound like I know what I'm talking about-whether it be to the press, other lawyers, or judges 1 am arguing in front of."189

The key point for this lawyer was that activists and patients knew the specific policy changes they wanted. What they did not know-and where the lawyer proved useful-was how, procedurally and mechanically, to accomplish these goals through the courts. In a sense, then, rather than having the lawyer guide and dictate strategy, the patients viewed the lawyerand the lawyer viewed himself-mainly as a vehicle for accomplishing their agenda.

Compare this interaction with the strategy used by the lawyers in the above-cited case involving the homeless, Olga Tellis. ${ }^{190}$ V.M. Tarkunde, one of India's most famous cause lawyers, was particularly prominent in this litigation. ${ }^{191}$ Born in 1909, Tarkunde received his law degree from Fergusson College in Pune, Maharashtra, and then received an advanced

\footnotetext{
183. Id.

184. Tellis v. Bombay Mun. Corp., 1985 Indlaw SC 161 para. 2, 20-21, 24, 27, 31-33, 37

185. Samity v. West Bengal, 1996 Indlaw SC 2871 para. 10-16.

186. PUCL v. India, A.1.R. 1997 Del. 395.

187. Supreme Court Legal Aid Comm. v. M.P., 1994 lndlaw SC 1642 para. 1-7.

188. K.C. Malhotra v. M.P., AlR 1994 M.P. 48; India v. S.J. Pandit, AIR 1997 Ker 152.

189. Interview with Anonymous Cause Lawyer, New Delhi, India (July 22, 2003).

190. The group of very prominent cause lawyers involved in representing the homeless included Indira Jaisingh, Rani Jethmalani, Anand Grover, Sumeet Kachhwaha,Ram Jethmalani, V.M. Tarkunde, Darshna Bhogilal, Indu Sharma, and P.H. Parekh.

191. See In Memoriam, Justice V.M. Tarkunde (1909-2004), PUCL Bulletin, May 2004, http://www.pucl.org/Topics/PUCL/2004/tarkunde-condolence4.htm.
} 
degree in law from the London School of Economics. ${ }^{192}$ Although he joined the bar in England, he soon returned to India to become involved with the Congress Socialist Party ${ }^{193}$ and joined forces with the "radical thinker and political activist" ${ }^{\prime 194}$ M.N. Roy, with the goal of advocating on behalf of "people at the grassroots level." 195 Tarkunde worked tirelessly to promote a secular, egalitarian, humanist society, both politically and through the courts. Eventually he was appointed to and sat on the Bombay High Court. ${ }^{196}$ But Tarkunde retired early (in 1969) so that he could resume championing the rights of the disadvantaged, which included helping to form the early incarnation of what has become one of the most renowned civil liberties groups in India-the People's Union for Civil Liberties (PUCL). ${ }^{197}$

In Olga Tellis, the Bombay city government had sought to relocate a group of "pavement dwellers" 198 under the auspices of an 1888, preIndependence ordinance known as the Municipal Corporation Act. ${ }^{199}$ Tarkunde, as one PUCL colleague remarked, vigorously litigated the case as he had many of his others. ${ }^{200}$ This individual noted how Tarkunde spent countless hours "living" with the homeless. ${ }^{201}$ He immersed himself in their culture to gain a firsthand appreciation of their day-to-day lives. ${ }^{202}$ Tarkunde found that although homeless, these pavement dwellers had an immense amount of self-pride and self-dignity, yet they were being treated by the local government as though they did not deserve even to live. In the Supreme Court, Tarkunde and his colleagues pressed the argument that the justices not discard or cast away these people. Ultimately the Court agreed, holding that the Constitution indeed affords all individuals the right to procedural due process under articlc 21 before the government can begin the process of displacement. ${ }^{203}$ In both the health care and homeless cases discussed above, then, lawyers did not act as elite, independent agents but instead cooperated with their constituents.

Though in many instances lawyers have sought to advance the civil liberties and civil rights agendas of grassroots movements by presenting

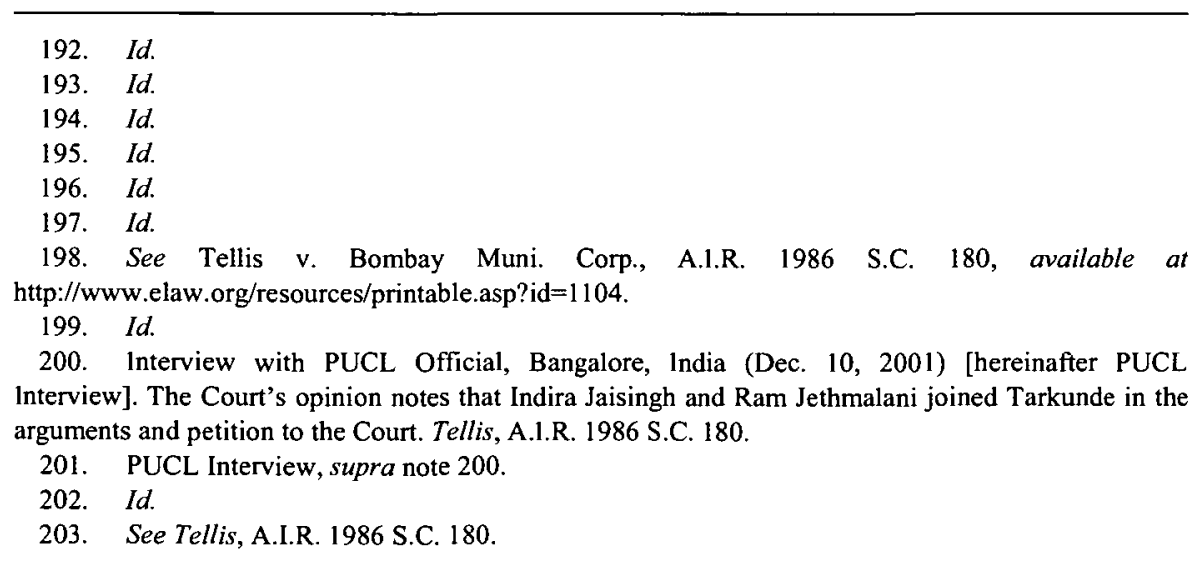


arguments around article 21, activist lawyers in India have exploited other constitutional provisions as well-and not just in court. Consider the reaction among a wide swath of people opposed to the famous Indra Sawhney decision $^{204}$ by the Supreme Court. In this landmark case, the lead petitioner invoked article $16(2)$-a constitutional provision that bars discrimination on the basis of caste and class ${ }^{205}$ - to argue that the central government's reservation of $27 \%$ of public jobs for "backward classes" violated his right freely to pursue meaningful employment. ${ }^{206}$ Although the Court upheld the program under article $16(4),{ }^{207}$ which gives the government great latitude to establish such a scheme, it did set a quota ceiling of $50 \%$ and also held that no reservations may be made in job promotions - a partial victory for the petitioner.

What ensued, however, were "politicians and political parties of all varieties [who] championed the cause of backward classes, giving the impression that reservation in government jobs and educational institutions [was] the ultimate solution for inequality and backwardness." 208 These groups, together with lawyers and other activists, worked to pass a constitutional amendment to overturn the Court's decision. ${ }^{209}$ Primarily relying on the tactic of lobbying, this coalition invoked the historical reasons for article I6(4)'s passage and stressed the continued need to ensure its vibrancy. Ultimately, they were successful in pressuring parliamentary leaders two years later to insert clause $4 \mathrm{~A}$ into article 16 , which "enabled the state (i.e. the Union and state legislatures) to make any provisions for reservations in favour of Scheduled Castes and Scheduled Tribes even in matters of promotion." 210

204. Sawhey v. India, A.I.R. 1993 S.C. 477.

205. INDIA CONST. art. 16(2) ("No citizen shall, on grounds only of religion, race, caste, sex, descent, place of birth, residence or any of them, be ineligible for, or discriminated against in respect of, any employment or office under the State.").

206. Sawhney, A.I.R. I993 S.C. 477. "Backward class" is a term of art that typically refers to lower castes and tribal villagers.

207. INDIA CONST. art. 16(4) ("Nothing in this article shall prevent the State from making any provision for the reservation of appointments or posts in favour of any backward class of citizens which, in the opinion of the State, is not adequately represented in the services under the State.")

208. Clark D. Cunningham \& N.R. Madhava Menon, Seeking Equality in Multieultural Societies (Oct. 17, 1997) (draft paper), available at http://law.wustl.edu/Conferences/Equality/art23.html\#fnB13.

209. See SATHE, supra note 89, at 94; see also Fali S. Nariman, Making a Mockery of Merit, INDIAN EXPRESS, May 22, 2000, available at http:/www.indianexpress.com/ie/daily/ 20000522/ied22048.html.

210. See Nariman, supra note 209. The identification of scheduled castes and scheduled tribes is important and seems purposive here by the Parliament. The amendment did not extend these types of reservations to all backward classes. However, aceording to S.P. Sathe, "the Law Minister [at the time] moving the bill [i.e. Amendment 4A] had promised in Parliament that a similar bill providing for reservation to promote the other backward classes would also be moved." Sathe also notes that the state of Tamil Nadu passed a law allowing for reservations to exceed the $50 \%$ marker set forth by the Indra Sawhney court. In fact, one year after the decision, the Parliament passed a constitutional amendment legalizing Tamil Nadu's program. SATHE, supra note 89, at 94. 
All these examples highlight a pattern similar to that found in women's rights efforts in India. Whether the issue is prisoners' rights, bonded labor, basic health care needs, the homeless, or the enduring effects of caste on daily life, when Indian civil liberties cause lawyers recast the immediate, material demands of the grassroots into constitutional claims, there can be a mutually interactive and dependent relationship between those formally advocating and those being represented. As the next Section illustrates, the same dynamic holds true for those who advocate for environmental justice.

\section{Cause Lawyering for Environmental Rights in India}

New Delhi-based cause lawyer M.C. Mehta is arguably the most prominent environmental legal activist in India. Like the activist lawyers discussed above, Mehta has relied extensively on the due process provision of article 21 as the basis for submitting article 32 petitions in the Supreme Court. The generality and flexibility of article 21 has allowed Mehta to pursue in court various environmental causes that are at the core of how people carry on their daily lives. ${ }^{211}$

He has, for instance, used article 21 to argue successfully that without stricter vehicle emissions standards, people's quality of life and their liberty to breathe clean air would be violated. ${ }^{212} \mathrm{He}$ also won a judgment prohibiting the dumping of industrial pollutants into lakes and rivers. ${ }^{213}$ And he prevailed in a case where the Court ruled that public and private owners of diesel-run, pollution-emitting buses could be held financially liable to the government's Director of Transportation. ${ }^{214}$ In almost all of Mehta's environmental cases, the government serves as the main defendant; Mehta has convinced the Court that the inability of the government to protect its citizens from environmental hazards violates the spirit of article $21 .^{215}$

India's constitutional framework and the spate of environmentallyfriendly judicial rulings have inspired Mehta to continue working as a legal champion for environmental protection. ${ }^{216}$ Mehta knows that he possesses the ability to transform words on parchment into effective constitutional rhetoric when advocating for an environmental cause in court. He is aware that his work has already made "legal history." 217 But he also recognizes

211. Telephone interview with M.C. Mehta (Dec. 11, 2001) [hereinafter Interview with M.C. Mehtal.

212. Mehta v. India, (I991) 2 S.C.C. 137. For two follow-up judgments, see also Mehta v. India, A.I.R. 1998 S.C. 2340; Mehta v. India, A.I.R. 1999 S.C. 291.

213. Mehta v. India, (1997) 2 S.C.C. 411.

214. Mehta v. India, 2002 Indlaw S.C. 1929.

215. See Indian Council for Enviro-Legal Action v. India, A.I.R. 1996 S.C. 1446; Interview with M.C. Mehta, supra note 211.

216. Interview with M.C. Mehta, supra note $21 \mathrm{I}$.

217. This term comes from an inscription noted on the Ramon Magsaysay Award for Public Service, given to M.C. Mehta in July 1997. 
that his efforts will be for naught if environmental activism is isolated in the judicial arena. Mehta, hence, is a strong proponent of bringing the law to-as well as learning from those at-the grassroots level. Since the vast majority of causes are promoted at this level, it is crucial that everyday Indians are aware of their rights, as well as their ability to shape the laws under which they live. ${ }^{218}$ Consequently, Mehta is conscientious about ensuring that the Constitution's promises actually mean something to people on the ground. For this reason, he devotes time not only to working in legal literacy camps in rural villages and educating the poor on various environmental issues, but also to learning about what issues are most important to them. ${ }^{219}$ In describing his role as the country's leading environmental litigator and also as one who works with and is educated by grassroots activists, he told a reporter from the Far Eastern Economic Review, "An environmental lawyer should not confine actions to the courtroom.",220

But Mehta is not the only environmentalist to recognize the importance of blending formal and grassroots advocacy. Medha Patkar is another well-known environmental champion who works on behalf of some of the most economically impoverished tribal Indians whose land has been condemned by the government. ${ }^{221}$ Patkar is a leader in the grassroots movement known as the Narmada Bachao Andolan (NBA), which since the early 1980 s has focused on blocking the construction of a government dam on the Narmada River. ${ }^{222}$ As Ashok Swain has commented, once completed the dam will be the second largest "in the world, and its reservoir [would] submerge a total of 248 villages with a population of 66,593 , covering 34,996 hectares in the states of Madhya Pradesh, Maharashtra, and Gujarat." 223 Overall, nearly two million people will be affected in some manner by the construction of the dam.

218. Interview with M.C. Mehta, supra note 2 II.

219. Mehta was, for example, one of the founders of the Indian Council for Enviro-Legal Action, and the founder of the M.C. Mehta Environmental Foundation, described as

a non-profit, non-governmental organization (NGO) working throughout India for the protection of the environment and citizens' rights. It provides a forum for citizens, NGOs and activists working for sustainable development and social change, and also provides opportunities for research, training and education on environmental and social issues for young lawyers and scientists. M.C. Mehta is using the foundation and its new facility to pass on his invaluable experience protecting the environment through law to a new generation of grassroots advocates around the world.

E-LAW Partners in Asia, http://www.elaw.org/custom/custompages/partnerDetail.asp?Profile_id=850 (last visited Nov. 20, 2005).

220. Vir Singh, Guardian of the Taj, FAR E. ECON. REv., Aug. 7, 1997, at 82.

221. Friends of the River Narmada is an affiliated website that supports Patkar's organization. See http://www.narmada.org/medha.html (last visited Nov. 20, 2005).

222. Ashish Kothari \& Shekar Singh, The Narmada Valley Project: A Critique (1998).

223. Ashok Swain, Democratic Consolidation? Environmental Movements in India, 37 ASIAN SURVEY 818, 826-27 (1997). 
To protest the government project, Medha Patkar has embraced a range of practices. She promotes the rights and customary traditions of rural citizens who face displacement, but in various venues she also emphasizes the moral obligation of the state to ensure that its citizens live free from environmental erosion. ${ }^{224}$ Although Patkar is a social worker rather than a lawyer, she knows well two nonjusticiable articles of the Indian Constitution, $48 \mathrm{~A}$ and $51 \mathrm{~A}(\mathrm{~g}){ }^{225}$ In her speeches and writings, she calls on the state to be mindful of how environmental policy has real-life ramifications on individuals, especially the poor. Her masterful use of this rhetoric has mobilized the grassroots throughout the country.

Yet, as she has noted, the impetus for her work is the passion exhibited by tribal villagers, who have mobilized to protest what they see as the destruction of their way of life. ${ }^{226}$ Professor S.P. Sathe has described how Patkar and the villagers initially employed a series of "Gandhian methods"227 to express their discontent. Their "scrupulous insistence on nonviolence"'228 included peaceful marchcs, protests, grassroots advocacy campaigns, and political lobbying. Yet these nonviolent tactics were often met with brutal repression from financially motivated state governments that wanted the dam construction to continue. ${ }^{229}$ As Sathe discusses, given that other disadvantaged groups had won protection in the Supreme Court, the villagers viewed litigation, in spite of the time it might take, as another nonviolent way to counter this state-sponsored violence. ${ }^{230}$ Lawyers for the NBA soon began to cast the government's dam project as an unconstitutional taking in violation of articlc 31 , a violation of Article 14's equal protection clause, ${ }^{231}$ and a violation of article 19(e)'s right "to reside and settle in any part of the territory of India."

In contrast to the many successes of M.C. Mehta, lawyers for the NBA have experienced a mixed set of rulings from the Supreme Court.

224. Kothari \& Singh, supra note 222. There are several websites dedicated to the work Patkar has done. See, e.g., Interview by Medha Patkar with Venu Govinda, The Face of Narmada, INDIA TOGETHER, Aug. 7, 1999, http://www.indiatogether.org/interviews/iview-mpatkar.htm; Interview by Robert Jensen with Medha Patkar, Z Acrivism ONLINE, Apr. 2004, http://zmagsite.zmag.org/ Apr2004/jensen0404.html; see also $Q$ \& A: Medha Patkar, THE Hindu, Mar. 28, 2004, available at http://www.hindu.com/2004/03/28/stories/2004032800971300.htm.

225. INDIA CONST. art. 48A ("The State shall endeavour to protect and improve the environment and to safeguard the forests and wild life of the country."); art. $51 \mathrm{~A}(\mathrm{~g})$ ("It shall be the duty of every citizen of India to protect and improve the natural environment including forests, lakes, rivers and wild life, and to have compassion for living creatures.").

226. See Tanmaya Kumar Nanda, The Narmada Story, InDIAlNFo.COM, Oct. 18, 2000, http://newsarchives.indiainfo.com/spotlight/narmada/narmada.html.

227. See S.P. Sathe, Supreme Court and NBA, Friends of River Narmada, Nov. 11, 2000, http://www.narmada.org/archive/epw/nov11.2000.sathe.html.

228. Id.

229. Id.

230. Id.

231. "The State shall not deny to any person equality before the law or the equal protection of the laws within the territory of India." INDIA ConsT. art. 14. 
The Court has had to balance the government's stated interests of pursuing a public-policy project that would create jobs, improve the power supply, and contribute to the economy against the interests of the local villagers. ${ }^{232}$ In 1998, the Court ruled against the NBA's petition to block the dam construction, but required the government to provide habitable "relief and rehabilitation" sites be provided to the displaced villagers. ${ }^{233}$ Upon a repetition by the NBA seeking a complete injunction against the government construction, the Court in 2000 refused to grant such a motion, prompting grassroots activists and the lawyers who represented them to criticize the decision on the grounds that the judgment contradicted the public interest ideals of the Constitution. In noting its disgust, the NBA stated:

The Supreme Court has violated thc spirit of the Constitution of India and democratic governance. The court has totally neglected the fundamental rights of the most vulnerable section of our society and also the serious issues raised regarding the propriety of the dam. Instead, it has provided a weapon in the hands of the powerholders to indiscriminately displace the project affected people and crush their rights ... The court seems to have done a disservice to the Indian Constitution, Indian democracy and Indian people. The judgment is unjustifiable, reactionary and hence, unacceptable. The NBA would fight against this injustice at the hands of the judiciary tooth and nail. We call upon the people of India who value democracy and Constitution to challenge this decision and ask the court to restore the people's rights in the Narmada valley. ${ }^{234}$

The NBA would again petition the Supreme Court, this time arguing that the rights of specific displaced villagers in the state of Madhya Pradesh (MP) had been breached by the government. In March 2005, the Court reiterated its earlier order that people involuntarily moved by the dam construction be justly compensated and relocatcd to habitable land. ${ }^{235}$ In its

232. For an article that describes the different positions that the Court had to consider on this matter, see V. Venkatesan, Threat of Submergence, 16 FronTLiNE, July 3-16, 1999, available at http://www.frontlineonnet.com/fll614/16140350.htm.

233. Narmada Bachao Andolan v. India, 1998 Indlaw S.C. 1602. The decision sparked angry protests from, among others, Medha Patkar and celebrated author Arundhati Roy. Both activists publicly and repeatedly chided the Court. In a subsequent ruling in 1999, the Court lashed back, warning that such "vicious stultification and vulgar debunking cannot be permitted to pollute the stream of justice." Narmada Bachao Andolan v. India, I999 Indlaw S.C. 780 para. 6. Aftcr another Court ruling in 2002, Roy was convicted of contempt of court after she refused to scale back her verbal and written attacks. She served one day in jail and paid a fine. See J. Venkatesan, Arundathi Roy Jailed for Contempt of Court, THE HINDU, Mar. 7, 2002, available at http://www.hinduonnet.com/thehindu/2002/03/07/stories/2002030706060100.htm.

234. Press Release, Narmada Bachado Andolan, Without Considering Basic Issues, Supreme Court Surrenders the Pressures by Power Holders (Oct. 18, 2000), http://www.irn.org/programs/ india/0010 I9.narmadapr.html.

235. Narmada Bachao Andolan v. India, 2005 Indlaw S.C. 24I. 
ruling, the Court chastised the state government for failing to pay compensation settlements to residents of two adversely affected MP villages and for not adequately offering replacement property; it ordered these remedies forthwith. ${ }^{236}$ Many, including Medha Patkar, praised the ruling. ${ }^{237}$ But the Court did not halt the overall dam construction, to the concern of some NBA supporters. ${ }^{238}$ Lawyers and activists thus continue to press claims on behalf of the villagers by drawing on the fundamental rights of the Constitution, and accordingly, they are considering submitting new petitions in the Supreme Court.

The equivocal attitude of the Court on the NBA dam project, however, has not deterred other environmental lawyers and grassroots activists from advocating for those most in need of basic environmental protection. For example, spurred on by a once nearly destroyed but yet presently vibrant and angry grassroots constituency, cause lawyers representing the victims of the 1984 Bhopal chemical disaster have sought to reopen the case. The lawyers have argued that the settlement between Union Carbide and the government of India (which represented the plaintiffs) ${ }^{239}$ has failed to remedy the unbearable suffering that still plagues the many thousands who were injured by the gas leak. ${ }^{240}$

In 2004 I spent time in Bhopal and witnessed firsthand the emotions of those devastated by this disaster. Even though two decades had passed, there were still grassroots activists who were more determined than ever to

236. Id.

237. Medha Patkar, Latest Judgment Proves It All, INDIA Together, Apr. 28, 2005, http://www.indiatogether.org/2005/apr/opi-vindicate.htm.

238. For reaction to the March 15, 2005, verdict, see Friends of the River Narmada website at http://www.narmada.org.

239. Sahu v. India, A.I.R. 1990 S.C. 1480 (permitting the government to step in and represent the interests of those who were victims of the gas leak).

240. The politics of the December 4, 1984, Bhopal disaster are quite complicated. Indeed, because of the terribly high number of cases backlogging the Indian court system (and the possibility of getting greater monetary damages in the United States), the Indian govemment pushed to have the case against Union Carbide tried in the United States (The government of India in 1985 passed the Bhopal Act, which allowed it to represent the victims of the Bhopal disaster in the U.S. courts.) The Indian government then came to the United States and hired what is today the law firm of Robbins, Kaplan, Miller \& Ciresi in Minneapolis to represent its interests. (Robbins had made its name in plaintiff's litigation with its lawsuit over the Dalcon Shield birth control devices.) The case was heard in the U.S. District Court for the Southern District of New York. Union Carbide in 1985 moved to have the case dismissed on grounds of forum non conveniens. In 1986, the district court granted this motion and transferred the case back to India. The case was then assigned to a district court in Bhopal, Madhya Pradesh, where in 1988 an Indian judge granted interim financial relief to the victims. This decision was appealed to the Madhya Pradesh High Court, which, although overruling the lower court's decision, curiously cited a British statute in granting its own interim relief to the victims. The case then was appealed to the Indian Supreme Court, which took the unusual step in February 1989 of structuring a settlement between the government of India and Union Carbide whereby the latter was to pay out $\$ 470$ million dollars in damages to the victims - a wholly inadequate sum according to representatives of the victims. We are past the twentieth anniversary of the Bhopal disaster, and, sadly, most of the victims still have not received compensation for their injuries. 
see that those who suffered so greatly finally receive fair compensation. Many of these activists were relatives of the dead. Through their mobilization efforts and eloquent pleas, they worked with cause lawyers to press the case that the victims to this day had not had their rights-to live a healthy life, free from illness caused by Union Carbide's tortious acts-realized.

In particular, as 1 was told during my visit, the victims and their families had initiated a petition in the Supreme Court seeking a declaration that the government of India release to them the remaining money (\$327.5 million dollars) it had obtained from the overall $\$ 800$ million dollar settlement reached with Union Carbide. In July 2004 the Supreme Court ordered the government to distribute these funds to the nearly 500,000 "victims and dependents" of this tragedy. ${ }^{241}$ As many of us who have followed these events know, even counting the $\$ 327.5$ million dollars, the total sum was a woefully inadequate amount given the devastation. Yet this recent victory provides some hope that legal action in the future by the victims might once again be successful (although, as one of the lawyers for the victims ominously reminded observers after the Court's ruling, "there's always a gap between the Court's orders and the way it is implemented, so we shall keep our fingers crossed"242).

\section{Conclusion}

The debate over why and how cause lawyers do what they do is one in which scholars have engaged for years. The literature to date has moved the discourse significantly forward by underscoring the many different aspects of cause lawyering and highlighting the varying opportunities, incentives, and constraints that are faced by those who pursue this legal path. To their immense credit, Austin Sarat and Stuart Scheingold's work over the years has generated a wealth of scholarship on cause lawyering, including recent and compelling studies that examine the interplay between grassroots demands and lawyers' responses.

I have sought to build on these latest works by focusing on how grassroots leaders can help cause lawyers understand the situations they and their constituents face, and by showing, both from a comparative and empirical perspective, how those at the grassroots level can shape the way cause lawyers deploy constitutional litigation. Although cause lawyers rely on varied forms of advocacy, constitutional litigation remains a "primary agent of liberal democratic cause lawyering."243 And while the conventional wisdom is that this strategy is lawyer-run, the evidence presented in

241. Court Relief for Bhopal Victims, BBC News (World Edition), July 19, 2004,

http://news.bbc.co.uk/2/hi/south_asia/3906691.stm.

242. Id.

243. SCHEINGOLD \& SARAT 2004, supra note 18, at 103. 
this study suggests that cause lawyers clearly do not make decisions on constitutional litigation independent of grassroots constituents.

This account will no doubt raise questions for some readers. For instance, some may wonder how representative my evidence is of constitutional cause lawyering generally, and even within India itself. After all, India's population is over one billion; can one possibly marshal the existing data accurately to extrapolate what is occurring in other parts of the country, let alone in other societies? In addition, some may argue that the issues on which I focus include a bias (and thus limitation) to my findings. Women's rights, civil liberties, and the environment readily lend themselves to mobilization and participation by the grassroots.

And then there will be those who suggest that I have romanticized the impact grassroots members can have on how lawyers use tactics like constitutional litigation. As I have been told by my skeptics, Supreme Court lawyers in India are, simply put, elitists. While lawyer-grassroots interaction may have been prevalent immediately after the Emergency Period, that happy marriage was short-lived. Today, Indian Supreme Court lawyers are isolated actors who generally are not concerned about receiving input from those on the ground. Because the Indian system allows lawyers to file petitions without even having clients, the advocacy in which these lawyers engage is likely to be more about personal ego-enhancement than about helping or listening to the grassroots. And all this should not be surprising, this argument goes, because in India caste and class hierarchy and the divisions between the "haves" and "have-nots" are as deeply entrenched as anywhere in the world. If, by chance, local leaders are affecting cause lawyering behavior, then it is more likely at the margins than directly; any interpretation otherwise only does a disservice to the study of legal mobilization in India.

In terms of sample size, for the reasons stated in Part III.C, the empirical evidence offered is only a snapshot of interaction between grassroots activists and cause lawyers in India. Obviously these findings may not necessarily be indicative of what is transpiring throughout India or among all cause lawyers. More testing is needed in different settings and along different issues to uncover whether the findings here are the norm or an anomaly. Yet to dismiss this study's findings on the basis of sample size or issue selection is myopic because it stultifies the asking of larger theoretical questions regarding cause lawyering, and it essentially casts aside much of the insightful socio-legal literature upon which this study is based-a literature that, without question, has increased our understanding of the legal profession.

As for romanticizing traditionally marginalized grassroots individuals' effect on constitutional cause lawyers, indeed, studies that concentrate on oft-overlooked populations or issues occasionally can be Pollyanna-ish 
and excessively laudatory. ${ }^{244}$ But the past two decades have seen a steady growth of careful works, on South Asia in particular, that focus on marginalized groups. ${ }^{245}$ Although these works vary in specific subject matter and methodological approaches, most are unified around the idea that for too long scholars have emphasized state and societal elites as being the main actors influencing how law and politics develop. As many of these studies show, however, dating back to colonial and even pre-colonial times marginalized populations at various periods have drawn upon their own norms, beliefs, and identities to become politicized agents capable of enacting social change, though not all such populations can and do behave in the same manner. ${ }^{246}$ To use Sarat and Scheingold's parlance, some have the opportunities or resources to become more mobilized while others face greater constraints. But because the evidence presented here shows awareness and mobilization among three sets of grassroots actors, it adds an important empirical layer to this burgeoning literature.

In sum, my hope is that this study will provide useful lessons for future scholars examining cause lawyering and state-and-society relations more generally, both in the United States and in other societies around the world.

\footnotetext{
244. One recent book that comes to mind is Werner MensKi, Hindu Law (2003), a 600-page opus which attempts to argue that various interpretations to date by legal and religious scholars of Hindu law have failed to detect and understand the fair, equitable, and comprehensively just nature of this ancient code. For an insightful, powerful critique of Menski's book, see Donald R. Davis, Jr., Traditional Hindu Law in the Guise of 'Post-Modernism: 'A Review Article, 25 Mich. J. INT'L L. 735 (2004) (book review).

245. The University of Virginia has put together a wonderful online bibliography of such works. For a wide array of citations, see http://www.lib.virginia.edu/area-studies/subaltern/ssmap.htm (last visited Nov. 20, 2005).

246. Id. Arguably the most renowned scholar writing on subalternality has been Professor Partha Chatterjee. For a selected sample of relevant works, see Partha Chatterjee, The Nation and Its Fragments: Colonial and Postcolonial Histories (1993); Partha Chatterjee, The Politics of the Governed: Reflections on Popular Politics in Most of the World (2004); Partha Chatterjee, Two Poets and Death: On Civil and Political Society in the Non-Christian World, in Questions of MODERNity (Timothy Mitchell ed., 2000).
} 
